Portland State University

PDXScholar

Fall 10-10-2014

\title{
"But There's a Black History Month": A Content Analysis of Ideological Framing and Presentation in White Nationalist Publications
}

Dylan Tomas Waite

Portland State University

Follow this and additional works at: https://pdxscholar.library.pdx.edu/open_access_etds

Part of the Sociology Commons

Let us know how access to this document benefits you.

Recommended Citation

Waite, Dylan Tomas, "'But There's a Black History Month": A Content Analysis of Ideological Framing and Presentation in White Nationalist Publications" (2014). Dissertations and Theses. Paper 2008.

https://doi.org/10.15760/etd.2007

This Thesis is brought to you for free and open access. It has been accepted for inclusion in Dissertations and Theses by an authorized administrator of PDXScholar. Please contact us if we can make this document more accessible: pdxscholar@pdx.edu. 
"But There's a Black History Month":

A Content Analysis of Ideological Framing and Presentation in White Nationalist Publications

By

Dylan Tomas Waite

A thesis submitted in partial fulfilment of the requirements for the degree of

\author{
Master of Science \\ in \\ Sociology
}

Thesis Committee:

Randy Blazak, Chair

Maura Kelly

Robert Liebman

Portland State University

2014 


\begin{abstract}
:
The political climate in America continues to become more polarized each year. The "left" and "right" political parties are locked in near-constant struggle and it is often the people whom they are meant to serve that suffer the harshest effects of this struggle. This mainstream political posturing and hostile behaviour has allowed for the continued presence, and some say resurgence, of racially motivated right-wing nationalist groups. Groups such as the Ku Klux Klan, the Aryan Nations and racist Skinheads have seen periods of strength and decline throughout American history. In the late $20^{\text {th }}$ and early $21^{\text {st }}$ Centuries they have begun to adapt their message to find acceptance in groups outside their own and plant the seeds of racial and ethnic bias and supremacy in minds not yet stricken with the illnesses of hate and bigotry.
\end{abstract}

This research examines the ideological framing of far-right White Supremacist groups in the United States. Discussion of political, nationalist and economic ideologies and the ways these ideologies are framed and presented to wider audiences are described.

Using content analysis, more than 50 editorials, articles and other writings from six of the most circulated newsletters produced by American based White Supremacist groups were examined. Thematic analysis and line-by-line coding allowed for the development of various codes related to nationalism, immigration, traditional supremacy and perceived political failure, as well as many others. 
Findings suggest that many White Supremacist groups and individuals are shifting away from the biological or genetic supremacist beliefs of a previous era. Instead adopting a racially motivated nationalist identity and positioning themselves as being engaged in a struggle for "white civil rights." While still vehemently racist and racially/ethnically biased they seem to have taken up this new position in order to thinly veil their racism behind a guise of nationalist pride and altruism. This is especially troubling when one considers that many hate crimes are committed by individuals with no formal affiliation to organized hate groups. These individuals are often racially radicalized in a slow process that starts with mainstream political beliefs and slowly progresses to more radical beliefs as they struggle to understand the world in which they live. 


\section{ACKNOWLEDGEMENTS}

I want to first thank Dr. Randy Blazak for his years of guidance and encouragement. From the first day of Introduction to Sociology until the last day of my graduate program he has served as a resource, a sounding board, and a friend. I also want to thank the other members of my committee, Dr. Robert Liebman and Dr. Maura Kelly, for their support and direction as I worked through the various iterations of this research project. Thank you all for agreeing to be a part of this project, though at times it may have seemed rather shaky. Thanks is also owed to the Department of Sociology faculty and staff as a whole. Thank you all for your help, attention and for keeping me on track.

I must also give thanks to Mark Pitcavage, his team at the Anti-Defamation League and also the staff of the Southern Poverty Law Center. The work of people like Mark Pitcavage and organizations like the ADL and the SPLC made my project possible. Their assistance proved invaluable to the undertaking of this project and I hope that some of the work contained in these pages will serve as appreciation and thanks for the tireless work they do in the stand against hate and intolerance.

To my friends and family, I wouldn't be here today if it weren't for your love, support, and reassurance throughout the years. This project was a labor of love only made possible by the foundation provided by you all.

To the other students of Sociology, Sonja, Neil, Kyla, the PSU Sociology Club and 
others, I thank you for your inspiration and passion. In the darkest of times your appreciation and passion for Sociology served as a beacon of light that drew me forward and bid me to press on in my own work.

Finally, to my cohort I give thanks most of all. This project is as much yours as it is mine. Not only this project, but no project would have been possible without you all. Heidi, Cristina, Robin, Bryan, James, Schaylee, Christa and Amanda, I've drawn inspiration and strength from you all and will continue to do so. I am forever in your debt. 
TABLE OF CONTENTS

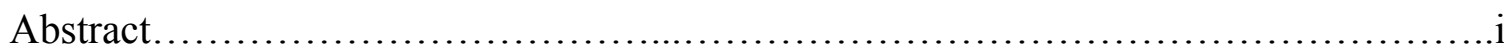

Acknowledgements....................................................................

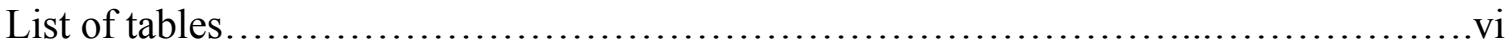

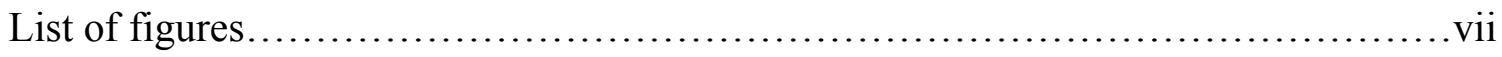

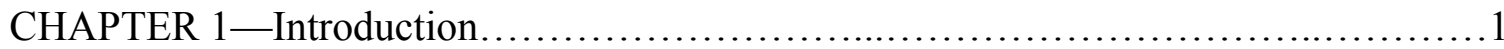

CHAPTER 2 -Literature Review..................................................

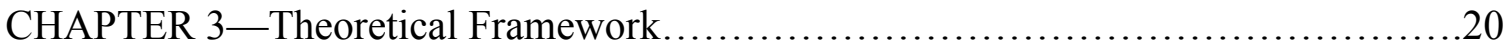

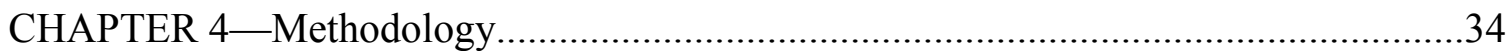

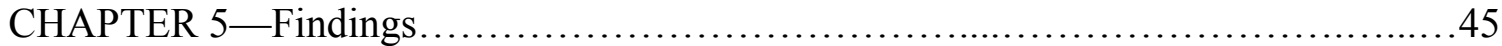

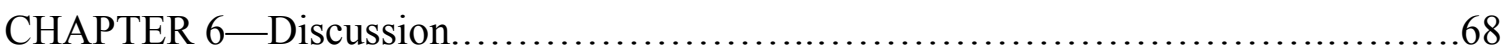

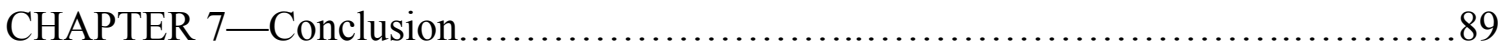

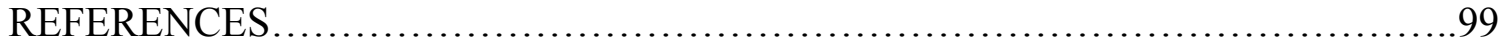

APPENDIX A-Publications used in sample ......................................102 


\section{LIST OF TABLES}

TABLE 1 - White Nationalist Publication Data................................. 35

TABLE 2-Summary of Code Categories, Codes and

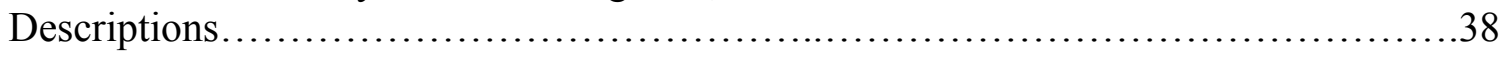

TABLE 3 - Summary of Total Applied Codes, Code Category Prevalence, Most Often Occurring Code and Sampled Publication Date Range .............................45

TABLE 4- Summary of National Socialist Movement Affiliation, Position, Highest \% Code Category \& Sample Date Range.

TABLE 5- Summary of National Alliance Affiliation, Position, Highest \% Code Category \& Sample Date Range....................................53

TABLE 6- Summary of American Renaissance Affiliation, Position, Highest $\%$ Code Category \& Sample Date Range..................................56

TABLE 7- Summary of American Free Press Affiliation, Position, Highest $\%$ Code Category \& Sample Date Range.................................59

TABLE 8- Summary of Occidental Quarterly Affiliation, Position, Highest \% Code Category \& Sample Date Range...

TABLE 9-Summary of First Freedom Affiliation, Position, Highest \% Code Category \& Sample Date Range. 


\section{LIST OF FIGURES}

FIGURE 1-White Supremacist \& Right-Wing Political overlap....................87 


\section{CHAPTER 1 INTRODUCTION:}

White supremacist. White separatist. Segregationist. Racialist. Racially aware. Racist. There are so many different ways that Caucasian Americans of a predominantly ethnic European lineage who espouse and buy in to a belief that ethnic/racial/religious groups maintain some fundamental difference are referred to and refer to themselves as. In her 2010 article Conservative and Right Wing Movements, Dr. Kathleen Blee notes that when studying and writing about far-right extremist groups or individuals, "Scholars and the rightists they study use somewhat different vocabularies (Blee, 2010, p. 270)."

Both Kathleen Blee, in her 2002 book Inside Organized Racism, and Leonard Zeskind, in his 2009 book Blood and Politics, use the term White Nationalist when referring the racial extremists that they study. This term is also commonly used by individuals active in or sympathetic to the causes and ideals of White supremacy. For these reasons I chose to use this term in my own project. The difficulty comes when trying to find any reasonably universal definition of White Nationalist, whether that be in academic or racial extremist circles. A difficulty shared by the attempts to define any nationalist groups.

After having done some preliminary reading of previous literature and the content identified for this project I began to see parallels between what I was reading and what I previously understood about Black Nationalism. In Black nationalism: A search for identity in America, E.U. Essien-Udom says that Black Nationalism "may be thought of as a belief of a group that it possesses, or ought to posses, a country; that it shares, or ought to share, a common heritage, way of life and ethnic identity that are distinct from 
those of other groups" (Essien-Udom, 1962, p.20). The similarities in these comments and the themes that I had begun to discover served as support for my use of the terms White Nationalism and White Nationalist. For this reason I made the decision to modify the Merriam-Webster definition of Black Nationalist. For the purpose of this research I define White Nationalist as "a member of a group of militant Whites who advocate separatism from the non-whites and Jews and the formation of self-governing white communities."

Defining White Nationalist in this way allows me to refer to groups and individuals in a general enough way to include neo-confederate, National Socialist and the Ku Klux Klan in a single discussion while being specific enough so as to omit militia groups, non-racial religious/social extremists and non-racist anti-government groups. This definition highlights Blee's point that terms like White Nationalist and white supremacist serve to bring attention to the common central theme among these groups and individuals, white racial dominance (Blee 2010).

The White Nationalist movement in America is not what it used to be. Hate groups, as defined and categorized by the Southern Poverty Law Center (SPLC), have been on the rise since the beginning of the $21^{\text {st }}$ Century. The SPLC reported an increase of approximately 400 hate groups between 2000 and 2012, with the largest increase (70 groups) coming between 2009-2010. The SPLC Intelligence Report published in spring 2014 reported that in 2012 there were 1007 hate groups in America categorized as Ku Klux Klan, Neo-Nazi, White Nationalist, Racist Skinhead, Christian Identity, NeoConfederate, Black Separatist and General Hate (SPLC 2014). That same spring the 
SPLC reported a 7\% drop in the number of "active hate groups" from 2012 to 2013; 1007 down to 939 . While this is a notable decrease their research suggests that the number of hate groups in the United States is still significantly higher in 2013 than it was in 2007, prior to the election of President Obama in 2008 (SPLC, 2014).

Membership in White Nationalist groups has fluctuated a great deal in the last $15+$ years. The Anti-Defamation League (ADL), a self-described human rights \& antihate organization, reports many major White Nationalist groups such as the Aryan Nations, White Aryan Resistance (W.A.R.) and the National Alliance are now totally defunct or barely even ghosts of their former selves (ADL 2014). Despite these challenges White Nationalist ideology, activism and support continue across the United States and even the globe. How is this possible? In the face of science, social awareness, increased exposure to the global community and greater access to information and knowledge how is it that White Nationalists have found a way to continue spreading their racially, socially and religiously divisive hate?

In A Force Upon the Plain: The American Militia Movement and the Politics of Hate (1997,) Kenneth Sterns draws the analogy of a recruitment funnel when discussing the militia movement in America and its strategy for gaining the support of individuals. He discusses militia recruitment and ideological presentation as a funnel that first uses very general issues as a means of gaining the attention of a greater number of people. Then slowly over time the exposure to militia ideology become more extreme. Along the way many individuals exit the funnel. But in the end there are almost always a few individuals who have made the journey from casual observer to devout believer. The 
questions that began to guide this research and would ultimately become the main research question then became:

What messages are used by White Nationalists to first draw individuals in to this funnel?

What messages are used by White Nationalist during the journey between observer and believer?

What messages are used by White Nationalist after the journey is complete in order to ensure individuals remain committed to the White Nationalist cause?

James Druckman paraphrases Cappella and Jamieson 1997, Gitlin 1980, and

Iyengar 1991 when he defines frames of communication as "words, images, phrases, and presentation styles that a speaker uses when relaying information to another (Druckman, 2001, p. 227)." It is these frames of communication that I am interested in exploring. The notion of these frames of communication when added to the questions born out of the idea of this ideological funnel led to the formation of a primary research question:

\section{What frames of communication are used by White Nationalists for the purposes of recruitment, indoctrination and the strengthening of existing beliefs?}

This project uses content analysis to examine print media organized, edited and distributed by various White Nationalist organizations and individuals. In order to explore the frames of communication used by White Nationalists I first needed to find content to analyze. There are an astonishing number of websites, magazines, blogs and message boards where groups of individuals share, learn, discuss and argue myriad White Nationalist beliefs, ideologies, conspiracies, "facts", rumors and more. Using both previous research and discussion with staff from both the ADL and the SPLC as a guide I decided on six different sources of printed media. For clarity I will call the items I 
analyzed newsletters. Though many of them read and are arranged more like D.I.Y. 'zines they are most often referred to as newsletters by both their creators, readers and other academics. With the help of staff from the ADL I was able to acquire 8-10 of the most recent "well circulated" WN newsletters. I also collected eight issues of a newsletter produced by the American National Socialist Movement.

Of the six publications chosen for analysis two, the National Socialist Movement (NSM) Newsletter/Stormtrooper \& National Alliance Bulletin, are from leading National Socialist (or Neo-Nazi) organizations. The First Freedom, is produced by an individual best described as a Neo-Confederate and anti-Semite. The American Renaissance, edited by Jared Taylor, presents WN belief through the lens of intellectualized white supremacy using "pseudo-scientific studies that attempt to demonstrate the intellectual and cultural superiority of whites and publishes articles on the supposed decline of American society because of integrationist social policies (ADL 2013)." The American Free Press, organized by Willis Carto, and The Occidental Quarterly, distributed by William Regnery and Kevin MacDonald, can both be classified as more generally White Nationalist as their content is written and consumed by various sects of the White Nationalist movement with no primary affiliation or connection to one group over another.

Previous research on White Nationalists has explored female members of the 1920’s Ku Klux Klan (Blee 1991), psychological profiles of White Nationalist leaders and members (Ezekiel 1995), the push-pull factors affecting male youth that bring them in to skinhead gangs (Blazak 2001) as well as a variety of case-studies, interview projects, quantitative examinations of existing data and analysis of White Nationalist 
discourse examining various presentations there in (Ridgeway, 1991; Daniels, 1997;

Ferber, 1998; Swain 2002). It is the latter of which I have drawn much of my motivation and guidance from for this project. Specifically the work of Jessie Daniels, for her 1997 book White Lies, and Abby Ferber, for her 1998 book White Man Falling. Both use a qualitative content analysis methodology in order to explore the presentations and interpretations of gender, race, class and sexuality in various White Nationalist magazines, articles, writings, letters and other printed media.

Where they looked at issues of race, class, gender and sexuality I've chosen to focus on political, economic, nationalist presentations within White Nationalist groups. With my research I that the $21^{\text {st }}$ century frames of communication for White Nationalist groups in an attempt to explore if they may have softened in an attempt to become more palatable to political and social conservatives and individuals who fall within the far-right political spectrum. Much like the Ku Klux Klan of the 1920's, I believe that White Nationalist groups today are trying to market themselves as the NAACP or American Black Caucus for White Americans. They have looked to past examples of successful social movements such as the American civil rights movement and begun to apply the lessons learned and those successful mobilization strategies to their own organizations and White Nationalist causes. For years members of White Nationalist groups or even unaffiliated White Nationalists have tried to enter political and social spheres and this trend continues.

Through their work focusing on the "how" and "why" of White Nationalist membership and ideology researchers such as Kathleen Blee (1991, 2002, 2005), Randy 
Blazak (2001, 2004), Raphael Ezekial (1995), Abby Ferber (1998, 2004), Jesse Daniels (1997) and others, to be discussed in the following chapter, have identified a great many frames of communication used to draw people in to the movement and culture of White supremacy. Messages surrounding lost economic and social status (Blazak, 2001), fighting back against cultural and social advances made by women and minorities (Ferber, 1998), attempts by White women to express traditional maternal roles (Blee, 2002) and White Nationalist groups providing a space for men to express heteronormative masculinity (Daniels 1997) have been discussed at length in the research of the past 30 years on White Nationalism and White supremacy.

Building on the work of those researchers already mentioned and those yet to be, and approaching the phenomena of White Nationalism from a position of Social Movements theory and the idea of Identity politics, I believe the modern strategy used by White Nationalists to draw individuals in to this ideological funnel is present themselves (referring to White Nationalist groups) as being no different than other racial/ethnic/social pride groups; to learn from successful social movements of the past and also to co-opt an appropriate and acceptable mainstream message in hopes of providing biased explanations and discussion at a later point. Despite a sampled content that only goes back to 2009 and a focus on the frames of communication used in that sample, I believe a strong case can be made that the latent frames of communication present in the findings of previous researchers are substantively different than the frames of communication discussed in this project.

Having presented a brief introduction to the White Nationalist problem in 
America and how I hope to have my research contribute to the existing body of research on this problem I will next present a two part literature review. The first part of the review serves to both highlight the successful research and academic exploration of White Nationalist groups as well as bring attention to gaps in the literature and research that my own work attempts to address. The second part presents the theoretical framework on which I have built my analysis. Using New Social Movements theory and the concept of Identity politics I examine these White Nationalist groups through a social movements lens and their publications has tools of recruitment, engagement and exposure.

A description of this analysis, the content collected and the research process follows the literature review and theoretical framework in the methodology chapter. I address sampling, data collection and the structure of the analytic process. Finally there will be a discussion section where I offer an explanation of my findings as they relate to the problem of white nationalism in America and make suggestions for the direction of possible future research as well as the implications of my findings on larger political discourse in America. 


\section{CHAPTER 2 \\ LITERATURE REVIEW:}

In order to fully understand the beliefs and foundations of the contemporary White Nationalist movement, it is necessary to have some background in some key concepts. First I will present a discussion on the White Nationalist movement in general, providing general background information on organized racist groups, as well as scholarly information that has been collected on the contemporary movement. Much of what is discussed here provided the foundation on which the coding and categorization process was built. Though I did not focus on gendered representations in my analysis the concepts, ideas, and observations of other academic professionals, who did, strongly influenced my analysis.

Finally an explanation of the theoretical framework used during the development, execution and analysis phases of this project is presented. It is important to define and explain these concepts and theories so that the reader may have a more comprehensive understanding of the study.

\section{WHITE NATIONALISM:}

The modern White Nationalist movement in America should not be thought of as a single unified organization but rather as a variety of porous, loosely affiliated groups in both America and Europe who have as much dissimilarity as they have common beliefs (Burris, Smith and Strahm, 2000). In her 1995 article titled "White Supremacy in the 1990's", included in Eyes Right: Challenging the Right Wing Backlash as edited by Chip Berlet, Loretta Ross notes that there are "only about 25,000 Americans are hardcore 
ideological activists for the white supremacist movement, a tiny fraction of the white population. They are organized into approximately 300 different organizations (Ross, 1995, p. 175)." The late 90 's and early part of the $21^{\text {st }}$ Century saw a dramatic increase in these numbers. In 2011 the SPLC reported more than 1,000 known hate groups. Though appearing to grow in respect to number of groups and also affiliated individuals these groups continue to operate in a notably disorganized and somewhat chaotic manner (SPLC, 2013). Old groups break-up and existing members may form new groups, join existing groups, remain unaffiliated or fade away and leave the movement entirely (Ridgeway, 1991).

There have been a significant number of projects that explore the experience of White Nationalist groups and their members. Researchers continue to look at the motivations behind white supremacist group membership and recruitment (Blazak, 1995, 2001, 2004; Ezekiel, 1995; Ferber, 1998, 2004; Blee, 1991, 2002). Projects designed to understand what brings men and women of various ages, classes, religions and social backgrounds in to White Nationalist groups have been and continue to be undertaken. Kathleen Blee's 1991 book Women of the Klan: racism and gender in the 1920's was one of the first attempts to gain insight and explore the experience of White Nationalists, in this case female White Nationalists. Blee's work was used as a foundation for the study of white supremacist group membership throughout the 1990's and in to the 2000's. Following up her work on female Klan members of the 1920's Blee wrote Inside Organized Racism (2002) and conducted interviews with female white supremacists in 
hopes of better understanding how they explained and understood their own experience as racist women in organizations that are highly patriarchal, misogynistic and violent.

Ezekiel found in his psychological study of White Nationalists that membership is very loose and often ill-defined. A single individual can be a member of multiple White Nationalist groups or not a member at all and simply an affiliate or friend of an existing member who supports the organization. He highlights the importance of collective identity formation in order to ensure the continued effective existence of the organization or group (Ezekiel 1995).

In his 2001 article "White Boys to Terrorist Men" Blazak highlights some factors that facilitate young males being drawn to white nationalism in a suburban community in Oregon. Through the use of ethnographic field observations and interviews with members of White Nationalist groups Blazak found that a profile existed for potential recruits. White Nationalists would target disaffected youth "because of their desire for structure, a subcultural solution to their anomie, as well as their need for consistent models of authority and masculinity (Blazak, 2001, 994)." On the subject of motivation Blazak writes that micro level psychological strain and macro level sociological strain creates an environment in which adolescents, particularly boys, are likely to be drawn to and influenced by White Supremacist ideology (Blazak, 2004). Five personal events are identified as being causes of significant psychological strain such that mechanisms of strain reduction offered by White Supremacists can motivate the individual to seek refuge within the group and eventually adopt racist ideology as their own. These strain events are (Blazak, 2004): 
1. A complex worldview based on moral relativism and negotiating shades of gray.

2. The inability to express aggression in a culture that decries violence.

3. A fear of changing physical and social environments.

4. The inability to attain specific goals.

5. Feeling blocked from social interaction.

In addition to the psychological strains that can develop within a person Blazak (2004) identified three "macroanomie" patterns:

1. Increasing change in constructions of masculinity and femininity.

2. Loss of socially defined status because of movement to reevaluate heterosexual, white, male power.

3. Lack of mainstream advocacy groups and movements for the "victims" of social change.

For individuals facing these internal and external challenges the simplistic, racialized White Supremacist ideologies can provide false but nonetheless desired, stability and create an understanding of the world not previously held by the individual.

The types of simple, gender and racially divisive ideology that recruits are exposed to often deal specifically with the perceived opposition to traditional notions of gender roles, hetero-normativity, racial division, and economic struggle that these young men are feeling. Whether they realize it or not, White Supremacists find ways to appeal to this sense of psycho-social confusion. They are able to offer not only simple answer to difficult questions but also a physical environment where it's "alright to be white" and a safe place to get away from the threat, real or imagined, of minority groups to the individual.

All White Supremacist groups exhibit some form of male supremacy that is often 
based on biological theories of gender division. Often they supplement this supremacy with action against those seen as inferior (Ferber, 1998, Kimmel and Ferber, 2000). The role of men in White supremacist groups is that of defender and warrior. The strength, superiority and dominance of the White race rests on a foundation of Aryan masculinity with racist ideology and politics providing the benchmark by which all other male prowess is measured. White Supremacist literature and media is rife with graphic and verbal depictions of the strong, racially aware White male on whose shoulders fall the task of defending the White race from extinction at the hands of Jewish conspiracy, genetic impurity resulting from inter-racial relationships, acceptance of homosexuality and/or the inability/refusal of White women to realize their full biological potential and repopulate the White race through the birthing of as many "pure" White children as possible (Daniels, 1997; Ferber, 1998).

White Supremacists speak of a racial divide that exists between Whites and all other minorities. It is this divide that minorities are attempting to cross and that must be defended by strong White men. Traditional, male dominated culture is seen as being representative of the natural order. Pseudo-scientific theories are often used as a means of "proving" male Caucasian superiority. Caucasians are thought to be naturally more intelligent and capable than minorities and men are thought to be naturally stronger and more capable than women. There are a number of historic and contemporary sources of this type of information and it often makes its way in to White Supremacist ideology (Berlet and Vysotsky, 2006). This assumption of innate biological superiority is a central tenet of every White Supremacist group reaching all the way back to the $19^{\text {th }}$ century 
Klan.

The gendered division of White Supremacist groups also comes largely from their history. When the Klan was first formed it was intentionally structured to be a male only organization. This was due in large part to the extremely violent nature of Klan activity during the first era of the Klan. Women did not make much of a presence in White Supremacist groups until the 1920's second era of the Klan. During this period they organized a formal Klan Women's Auxiliary and worked to support the efforts of the Klan as a political movement (Blee, 1991). As new White Supremacist groups began to develop in America the gendered inequality that was present in society naturally carried over. White Supremacist men drew on their personal knowledge, experience and bias when they began to organize these new hate groups and this meant that men were recruited in order to defend the White race while women were allowed to tag along and support the white race. White Supremacist men identified white women, children and families as that which needed defending while women were left to accept this decision and support it by maintaining the home, keeping the family and providing children for the family.

The continued presence of white supremacist groups in America has also given some researchers cause to study the specifics of how hate groups form and why they form in the areas they do (Woolf and Hulsizer, 2004; Goetz et al, 2012). Despite the ever growing national and international advances toward racial and religious equality the Southern Poverty Law Center counted more than 900 hate groups in the United States in 2013. Using the SPLC "Hate Map" and census data Goetz et al conducted a quantitative 
analysis of possible socioeconomic factors that may influence the development of hate groups in the United States. Their findings ultimately suggest that areas with "higher per capita income taxes, unemployment rates and divorce rates are associated with more hate groups (Goetz et al, 2012, 388)" They also note the importance of community social capital and its apparent ability to serve as a counter-offensive to the formation of hate groups.

Woolf and Hulsizer take an alternate approach in their 2004 study of the formation and continued presence of white supremacist groups in America. They sought to identify the psychological mechanisms at work in the individual leadership, members and recruits involved in white supremacist groups. Their stated goal in conducting this research was not to assist in the formation of hate groups but rather to identify these mechanisms in hopes of providing a foundation on which to build programs and policies that would combat the formation of hate groups. The results of this study find that there are a number of social psychological factors that are at work in the formation of hate groups. The importance of leadership is highlighted as being something that is not necessarily associated with a particular type of individual but rather a number of specific social mechanisms that the leader must understand. It is suggested that members of hate groups and other destructive groups i.e. cults share personality characteristics that appear to make them vulnerable to recruitment. Some of these factors include "desire to belong, lack of self-confidence, naïve idealism and cultural disillusionment (Woolf and Hulsizer, 2004, 47)." Like Goetz et al, Woolf and Hulsizer present their findings and conclusions as a tool of influencing or developing policies that will ultimately serve to combat hate 
groups and educate populations where recruits are drawn from.

One piece of the White Nationalist world that lacks the same degree of attention and depth of study is the ideological framing used by White Nationalists. Research done by Abby Ferber, for her 1998 book White Man Falling, and Jessie Daniels, for her 1997 book White Lies, has examined White Nationalist publications for the purpose of investigating "the white supremacist imagination (Daniels, 1997, p.1). Professor Carol M. Swain chose to explore the modern White Nationalist movement and its strategies in her 2002 book The New White Nationalism in America: Its Challenge to Integration. Dr. Swain approaches the White Nationalist movement in a very direct manner by saying:

...the new White Nationalist movement, while similar in some important ways, also differs very significantly from the older white nativist and white supremacy movement out of which it in some sense has grown. (Swain, 2002, p. 3)

It is these works that I used largely as a foundation for my project, though my focus and methodology proved to be a synthesis of sorts. Both Ferber and Daniels explored the intersections of gender, class, and race within White Nationalist discourse. Their focus was on gendered frames of communication as presented in White Nationalist publications very similar to those I examined. Dr. Swain examined White Nationalism, looking for ideological presentations similar to those explored in this research though her data sources were interviews, case studies, reviews of national surveys and focus groups with individuals of various ethnic and racial groups on topics such as affirmative action.

White Nationalists present an idealized "white" citizen when they discuss themselves, their history or their place in the social, racial and economic hierarchy that 
exists in America. The importance of the white American male is often over emphasized as Jessie Daniels points out:

The centrality of white men in white supremacist discourse is epitomized by an illustration regularly published in WAR (White Aryan Resistance). The image is of a white man, with airplanes and bridges in the background, and the accompanying text reads, 'White Men Built This Nation, White Men Are This Nation! (emphasis in the original)' (Daniels, 1997, p. 34)

This emphasis on the historical importance and presence of white Americans, men especially, is just one of the foundational points used in the development of my own analysis. Representations of white men as warriors, defenders of the white women, paragons of virtue are rife within White Nationalist discussion and publication. Strong white men in possession of a white racial identity are seen as the goal every white man should strive for and the object of desire for every white woman (Daniels, 1997; Ferber, 1998, 2004).

Swain also highlights the importance of developing a European-American identity, fostering racial and ethnic pride and celebrating the achievements of the White race and Europeans over other races or ethnic groups (Swain, 2002). White Nationalist ideological framing and presentation as noted by Ferber and Daniels in the mid-90's is different enough from that presented by Swain in the early 2000's and this is the research gap that this project attempts to address.

Other core themes that are often found throughout White Nationalist discourse are: white victimization (Daniels, 1997), economic and political threats (Daniels, 1997), a dualist frame of reference (Ferber, 2004) and also deeply anti-Semitic conspiratorial beliefs (Daniels, 1997; Ferber 1998, 2004). These and other themes within White 
Nationalist discourse appear to serve as the foundation for various fundamental values shared by all or nearly all White Nationalist groups (Roleff, Cothran and Torr, 2001). And it is through these values that White Nationalists find justification for their beliefs. Having identified recurrent themes and the values they seem to represent the question then becomes in what ways are they presented so as to gain the attention of a sympathetic public who will make the transition from ideological newcomer to devout believer? It is here that the concept of Identity politics comes in to play and will be discussed.

I have shown that much of the research done on White Nationalist groups has focused on the "why", "how", "where" and "what". Blee (1991) explored why women of the 1920's joined the Ku Klux Klan and found much of it was because they saw the Klan as supporting social, political and religious issues they felt were important. Blazak (2001) highlights how White Nationalist group membership serves the reclamation of a strong masculine identity. Both Daniels (1997) and Ferber $(1998,2002)$ illustrate what White Nationalists have to say about traditional gender roles and the place and purpose of White men and women within White Nationalism. Goetz et al (2012) find that hate groups can develop almost anywhere and there are only a few common characteristics in economic or social geography that are related to their formation. Despite differences in methodology, population of interest or even theoretical approach all of these studies have one thing in common. They don't address or explore the message presentation strategy, the frames of communication, used by White Nationalists as they address their specific audiences and the larger White American audience from which they hope to gain more support. 
Those presentation strategies, those frames of communication, constitute the focus of this project. Combined with a theoretical approach grounded in New Social Movements Theory and the idea of Identity politics, this project serves to address a missing piece of the puzzle that is the understanding and examination of White Nationalist groups, ideologies and activity. 


\section{CHAPTER 3 \\ THEORETICAL FRAMEWORK:}

A common theme found throughout much of the previously mentioned research is that of oppression. White Nationalists routinely express feelings of oppression at the hands of political liberals, feminists, homosexuals, minorities, Jews, the government or any combination of these and other groups. Development of a biased world view is often seen as a result of this oppression. Membership or affiliation with White Nationalist groups can be motivated by a desire to stand against this oppression.

The formation of a White Nationalist identity and the collective action that this identity may lead to highlight the need for White Nationalism to be explored as a social movement engaged in "identity politics." In her discussion of the new White Nationalist movement, Carol Swain notes that White Americans have begun calling for White solidarity and White identity using the same sorts of frames as minority group members. This newly adopted brand of identity politics has been seen to be successful for minorities as a means of advancing group interest and building group identity (Swain, 2002).

In order to better understand the connection between the White Nationalist goals, their message and how they use that message to meet their goals, a discussion of collective action frames and the framing process must take place. The ideas of frames of communication and frames in thought, when applied to the White Nationalist message, are better understood in relationship to these groups when presented alongside the concepts of framing as it relates to social movements specifically.

Moving forward with this chapter I will provide definitions and discussion of 
collective action framing, the framing process, social movements, New Social Movement theory and identity politics. This theoretical approach will support the case that White Nationalist movements in the United States are adapting the lessons of previously successful social movements and intentionally blurring the line between mainstream organizations and fringe groups.

\section{COLLECTIVE ACTION FRAMING:}

For many individuals, maintaining a specific ideology, being of a certain opinion about the collective group circumstance and holding a particular view of the world in which they live is not enough. They feel compelled to not only discuss these views and beliefs with others but also to educate the general public to the "truths" that they hold so dearly. They hold that some policy, practice, social structure or organization needs to be changed. It is the collective journey for change that makes these actors part of a movement and not simply a group of people engaged in discussion. This journey involves spreading their ideology, their opinion and their world view through the use of a deliberately crafted message. The movement actors are agents of action "engaged in the production and maintenance of meaning" (Benford and Snow, 2000, p.613) for fellow actors, members of the opposition, and those surrounding the periphery. The way that the message is packaged and presented, the frame, is very important, depending on whom the message is for.

The creation and use of frames, along with the construction of their meaning is referred to as "framing” (Gamson et al, 1982; Snow et al, 1986; Snow and Benford, 1988) and this framing activity is intentional, active, dynamic and evolving, and serves to 
create new frames that may either differ from existing ones or challenge those already present (Benford and Snow, 2000). The frames produced by movement actors in this manner are referred to as "collective action frames" and as one might expect these collective action frames serve to "mobilize potential adherents and constituents, garner bystander support and demobilize antagonists" (Snow and Bendford, 1988, p. 198).

Social movements use these action-oriented beliefs and meanings to rally support for their cause and give a sense of legitimacy to the activities of the group (Benford and Snow, 2000).

\section{THE FRAMING PROCESS:}

These collective action frames are not simply pulled from thin air. In their article "Framing and Social Movements: An Overview and Assessment", published in 2000, Benford and Snow note that:

...literature suggests that frames are developed, generated, and elaborated on not only via attending to the three core framing tasks discussed above, but also by way of three sets of overlapping processes that can be conceptualized as discursive, strategic, and contested. (Benford and Snow, 2000, p. 623

It is these overlapping processes that are of most benefit when considering the theoretical approach taken in regard to this research.

\section{Discursive Processes:}

The acts of speech and communication associated with movement groups and that movement actors engage in are referred to as discursive processes. The creation of collective action frames involves two discursive processes that can operate simultaneously or independently, frame articulation and frame amplification or 
punctuation (Benford and Snow, 2000).

Frame articulation comprises of the collection, linking, and intentional organization of events or group experience in order to provide and present an integrated, persuasive message to the consumer. Snapshots of the movements' subjective "reality" are packaged and presented to a variety of audiences differently, depending on the audience and the intended result. The piecing together and expression of these events so that a new or different point of view is provided is the key component of frame articulation (Benford and Snow, 2000).

The second discursive process, frame amplification, is precisely what it sounds like; the process by which movement actors bring attention to and point out some topic, belief, event or issue as being more relevant than another. The amplified elements of the message often provide the means of linkage necessary for frame articulation.

An unpublished report by DA Snow and J Miller, cited in Benford and Snow (2000) serves as an example of these discursive processes. Snow and Miller conducted an ethnographic study that explored how these two processes "contributed to the development, elaboration, and maintenance of a number of overlapping collective action frames within a radical, right-wing group in Arizona" (Benford and Snow, 2000, p. 623). They found that through the course of interaction these frames are routinely restructured and reimagined and that through an examination of how these discursive processes are employed a better understanding of the evolution of the collective action frames can be achieved (Benford and Snow, 2000). 


\section{Strategic Processes:}

Just as collective action frames are not plucked from thin air, neither are they employed in a random or careless manner. The frames used by a given group are intentional, calculated and focused in order to achieve some goal, which often depends on the consumer of their message at a given time. The strategic process by which a movement attempts to align their interests and frames with those of a given target audience has been referred to by Snow et al as "frame alignment processes" (1986) and four processes have been articulated and discussed by researchers: frame bridging, frame amplification, frame extension and frame transformation, though for the purposes of this study I have focused on frame amplification and frame extension.

As with the discursive processes, frame amplification refers to the tendency of social movements to fixate on existing values and beliefs and present them as being of greater significance or importance than others. This allows the social actors to more easily tap in to the conscience of those individuals whom they wish to target for recruitment, indoctrination or mobilization (Benford and Snow, 2000). The importance of frame amplification seems obvious and its use reasonably widespread across various social movements, researchers such as Mitch Berbrier report that it is particularly necessary to those movements who suffer at the hands of social and dominant culture stigmatization due to the maintenance of ideologies contradictory to those deemed appropriate or socially acceptable (Berbrier 1998).

The second most applicable strategic framing process is that of frame extension. This refers to a social movement and its actors portraying and presenting their interests, 
goals and frames as reaching beyond those primarily discussed and presented. It is the attempt made by social movements to convince non-involved actors that the movement cares about and is focused also on issues of concern to the non-involved actor (Benford and Snow, 2000). This is often an area where social movements of a similar style, type or who share goals and strategy come to a conflicted meeting. Often because they are each trying to gain the attention and support of the same target population. This type of conflict illustrates the fact that the framing processes utilized by social movements are routinely challenged and are always being adapted and converted (Benford and Snow, 2000).

\section{Contested Processes:}

It's not easy for social movement actors to their target population with frames or messages that might be new, foreign or counter to those that members of the population expect or already deem acceptable and a part of their subjective reality. Social activists can't expect to emplace their personal, or the movements, version of social reality on an individual without some struggle. Benford and Snow discuss that research suggests three major manifestations of challenge that social movement actors tend to face: movement opponents, bystanders and the media engaged in counter-framing; inter-movement frame disputes; and the debate between frames and events (Benford and Snow, 2000).

Though inter-movement frames disputes are common among White Nationalist groups it is the idea of counter-framing that is most interesting and useful for this project as it directly relates to the cyclical nature of much White Nationalist discourse. The cycle of framing and counter-framing as it relates to the White Nationalist movement is most 
simply presented as such: White Nationalists engaged in framing activity and develop a collective action frame in response to some issue, policy or practice with which they take offense; the opponents of White Nationalism develop a counter-frame that serves as a rebuttal or response; White Nationalist groups or individuals respond with further reframing meant to address, limit or reverse the counter-frames presented by opposition groups. The notion of counter-framing aided in the development of the "White Nationalist Victimization" code used during analysis.

\section{IDENTITY POLITICS:}

Identity politics can be defined a variety of ways but for the purpose my research and the use of New Social Movements theory, which I will discuss in greater detail shortly, I'm defining it using Cressida Hayes' definition found in the Stanford Encyclopedia of Philosophy. That definition reads:

1. a wide range of political activity and theorizing founded in the shared experiences of injustice of members of certain social groups 2. identity political formations typically aim to secure the political freedom of a specific constituency marginalized within its larger context 3. that constituency assert or reclaim ways of understanding their distinctiveness that challenge dominant oppressive characterizations, with the goal of greater self-determination (http://plato.stanford.edu/archives/spr2012/entries/identity-politics 2012)

As discussed in the previous section White Nationalists have and do align with all three of these points. They engage in and support a variety of political activity born of a sense that they have experienced injustice as a result of their whiteness. They actively seek to secure expressions of their political freedom and highlight the instances where they are attacked physically, legally or politically for those expressions. Finally they have made numerous attempts to bring attention to their unique and distinctive struggle at 
the hands of oppressive minority-focused governmental policies and practices.

In a review of the research on identity politics Mary Bernstein (2005) discusses the work of Alain Touraine when she writes “...he (Touraine) does consider conservative social movements as identity politics because they respond to economic globalization and the decline of national culture [Touraine, 1998, p.131] (Bernstein, 2005, p. 55)" The work done by Blazak, Blee, Ferber, Ezekial and others speaks directly to membership in White Nationalist groups being a response exactly as Touraine discusses it. Bernstein points out that, for Touraine, social movements need to have exclusive tendencies and singular status identities rather than be centered on multiple status identities that may vary between exclusive and inclusive (Bernstein, 2005).

For White Nationalist groups the singular status identity they focus on and rally behind is "whiteness." It is the perception of threats to this whiteness that White Nationalist groups use as a foundation on which to organize. White, Caucasian, Aryan, and European-American are much more than racial or ethnic identifiers. They are at the core of a White Nationalists being. It is from this singular characteristic that all other identities are born. Every sect of White nationalism finds a common voice in this identity and develops a worldview that allows them to see themselves as victims when it is challenged or threatened. The formation of this White identity is an essential condition for group mobilization.

There are two key components to an identity. First, social substitutability must be possible (Gardiner, 2005). This means that one in-group member is interchangeable with another in-group member but not an out-group member (e.g. any White Nationalist at a 
rally is seen as a friend and supporter regardless of affiliation). The second key component is "proximity of an out-group, the members of which are socially substitutable for each other, but for whom no member of one's own group is substitutable (Gardiner, 2005, p. 70)." The best example of this from the point of view of a White Nationalist is simply a non-White person. It doesn't particularly matter if a person is black, Hispanic, a Jew or a feminist as they are all enemies of and threats to the White Nationalist livelihood and station in life. The formation of this White identity and all of its possible racially, ethnically or socially influenced permutations are what White Nationalists use as a means of gaining the attention of a larger audience in hopes of identifying any like-minded sympathizers that may eventually join the ranks of the movement.

Gardiner notes that, as a response to Jim Crow, African-Americans were able to successfully employ the strategy of identity politics when they began "drawing on both the discourse of individual rights and an appeal to blacks based on common experience of racialized oppression (Gardiner, 2005, p. 70).” The effective application of this identity politics model found itself being adopted by numerous "new social movements" of the 60's and 70's. Through the classic employment of identity politics these new social movements found themselves able to recruit new members and activists using an appeal to general or specific types of oppression felt by members of a given target group. As they began to gain position, power and legitimacy they were able to apply moral and legal pressure on the greater dominant society at large. They did this by rallying for fair treatment on a national scale. They also found themselves working toward the most 
essential component of identity politics—recognition (Gardiner, 2005). With recognition by the larger societal structure these movements found the key to continued participation in their respective fight and played a role in the reorganization of social and legal policy structures in the United States (Gardiner, 2005, p. 71).

Having successfully employed the use of identity politics allows White Nationalist groups to recruit, organize and structure themselves in a semi-autonomous and self-sustaining way. Once they have a foundation of members and a model by which they're able to recruit more they can then move on to formal organization and the larger task at hand: gaining recognition, legitimacy and ultimately enacting the social, political and economic change they see as necessary for the continued future of White America. SOCIAL MOVEMENTS:

Susan Olzak (2004) writes in her chapter for The Blackwell Companion to Social Movements titled Ethnic and Nationalist Social Movements that "the study of ethnic and nationalist social movements lies at the intersection of three fields: social movements, race and ethnic collective action and nationalism (Olzak, 2004, p. 666).” It is at this intersection that I find myself as I begin to try and understand White Nationalist movements from a New Social Movements theory perspective. Let me start by saying that the way I've been using the term "nationalist" thus far is slightly different than Olzak uses it. I have been using "nationalist" to mean "a member of a group of militant Whites who advocate separatism from the non-Whites and Jews and the formation of selfgoverning White communities."

Olzak uses three important definitions that I find inform my research and this 
project very well. First she defines social movements as involving "purposive collective actions that voice demands for fundamental changes in political or economic arrangements in a society (Olzak, 2004, p. 666).” She draws an important distinction between social movements and sporadic collective action by pointing out that sustained collective action and a support for a sustained set of values is what sets social movements apart (Olzak, 2004).

Using the example of backlash by White Americans against Reconstruction era policies in the South Olzak brings attention to what she calls "reactive ethnic movements (Olazak, 2004, p. 667).” These types of social movements often express explicit concerns or objections directed toward a particular race, ethnic target or government authority. Claims made by ethnic and racial social movements are often based upon a unique and specific identity held by movement participants and defined by racial or ethnic markers (Olzak, 2004). This definition provides for the inclusion of White Nationalist group as an ethnic social movement, though there is certainly room for discussion as to the degree to which White Nationalist can legitimately express these types of concerns.

Nationalist movements are said to be to those movements that specifically seek to claim some degree to territorial sovereignty (Hechter, 2000). Nationalist movements may or may not be motivated by racial or ethnic factors but often territorial claims are based on the real or presumed racial or ethnic histories of a particular group. This provides for many shared themes between nationalist movement and ethnic/racial movements. (Olzak, 2004). It is important to note that the assertions made by nationalist 
movements reflect claims of authority or self-determination that are not currently being met (Olzak, 2004). Again we can see how White Nationalist groups in the United States fall within the defining limits of social movements that Olzak sets out.

\section{SUMMARY:}

The development of collective action frames is an integral piece of any social movement plan for success. Without them the movement is unable to articulate its goals, or purpose for existing. Collective action frames serve to recruit new members, mobilize existing members and provide support for the continued action and presence of the movement. The idea of collective action frames and frames of communication can easily be combined; collective action frames of communication could easily be discussed as being the "words, images, phrases and presentation styles that a speaker uses..." (Druckman, 2001) in order to "inspire and legitimate the activities and campaigns of a social movement organization" (Benford and Snow, 2000). And it is precisely this conjoining of academic philosophies that this project addresses.

What previous research in to White supremacy and social movements shows us is that White Nationalists have learned from the new social movements of the 60's and 70's (Gardiner, 2005). They recognize a model that has been successful in calling attention to oppressive and discriminatory practices, policies or actions directed toward a victimized in-group by a tyrannical controlling out-group. They also hope that eventually their constituency will grow to such a degree that they are able to effect necessary (in their eyes) change and successfully reclaim lost privilege, status, authority and freedom (Ferber, 1998; Daniels, 1997). 
I've also brought some attention to the ways that previous research has been done on White Nationalist groups and individuals and the resistance to approach research on these groups from a social movement theoretical perspective (Bernstein, 2005).

Admittedly there is some difficulty and concern in using new social movement's theory or identity politics to examine White nationalism. These types of groups don't fit well into the "social movement's box" created by studies of feminism, the New Left and the civil rights movement (Blee and Creasap, 2010). But as Blee and Creasap point out in there reference to Stein's 2001 piece "The Stranger Next Door," social movement theories are useful for guiding attention and directing focus to research that explores how right-wing movements begin, how members frame their respective messages, strategies of cooperation between rightist political groups and right-wing extremists and also the ways that these groups foster the development of a collective identity among members (Blee and Creasap, 2010).

It is not my intent to be critical of Ferber or Daniels in my attempt to explore the importance of nationalist or political ideology presented in White Nationalist discourse. Nor am I criticizing Swain's methodological approach to her study of White Nationalist political ideological framing and recognition of a new strategy among these groups. Instead this project serves to address Swains' topic of interest, new White Nationalism and its ideological framing, using Ferber and Daniels methodological approach, content analysis of current White Nationalist publications.

These studies of White supremacy and approaches to the exploration of social movements informed the development of my research question and also the 
methodological approach used to try and answer that question. Having just discussed previous research and support for the use of a social movement theoretical framework I will next address the methodology employed during my research. 


\section{CHAPTER 4 METHODOLOGY:}

In this section I review the methods used during this project, how the content was collected, how the decision to use these methods was made, and how the codes for the analysis were developed. I will also briefly discuss strengths and limitations of the sample and the manner in which the content was identified for analysis.

As noted in 1997 by Jessie Daniels "circulation figures for these (White Nationalist) publications are impossible to come by (Daniels, 1997, p. 140). Knowing this I followed her lead and went to an anti-hate group for help in identifying the publications that would provide me the greatest amount of useful and appropriate content. I contacted Mark Pitcavage, Director of Investigative Research at the Anti-Defamation League, and explained my project and my focus on nationalism, political ideology and White Nationalist defense of White America. I also explained that I was looking for current issues of those publications that either had the greatest circulation or were longest in publication. The intent of these criteria was to aid in the identification of publications that have credibility within the White Nationalist community and also to make an attempt to include content that would be generalizable to the majority of White Nationalist discourse. After our discussion I was sent pdf files of recent issues of five publications that he and his team at the ADL felt best fit my interest. I added these to the most recent issues of the newsletter that is produced with some regularity by the National Socialist Movement headquarters out of Detroit, Michigan. This gave me a total of 44 total issues of White Nationalist publications.

The 44 newsletters were comprised of multiple issues of six different publications 
written, edited, contributed to, and distributed by various White Nationalist groups and/or individuals. It should be stated very clearly that despite some ideological differences among the various White Nationalist groups they are all committed to reclaiming and/or maintaining white racial dominance in America. They also hold the belief that "whiteness" is an essential identity in which being White is superior to being non-White (Daniels, 1997). Though the newsletters are from various corners of the White Nationalist realm I am confident that they contain material representative of White Nationalist belief, ideology, action and intent.

\begin{tabular}{|c|c|c|c|c|}
\hline \multicolumn{5}{|c|}{ TABLE 1: White Nationalist Publication Data } \\
\hline Publication & Location & $\begin{array}{c}\text { Organizational } \\
\text { Affiliation \& } \\
\text { Year Founded }\end{array}$ & $\begin{array}{c}\text { Ideological } \\
\text { Position }\end{array}$ & $\begin{array}{c}\text { Date } \\
\text { Range of } \\
\text { Collected } \\
\text { Sample }\end{array}$ \\
\hline $\begin{array}{c}\text { NSM } \\
\text { Magazine } \\
\text { (8 Issues) }\end{array}$ & Detroit, MI & $\begin{array}{l}\text { National } \\
\text { Socialist } \\
\text { Movement } \\
\text { (1994) }\end{array}$ & $\begin{array}{l}\text { White Civil } \\
\text { Rights }\end{array}$ & $\begin{array}{c}\text { April } \\
2009- \\
\text { September } \\
2013\end{array}$ \\
\hline $\begin{array}{c}\text { National } \\
\text { Alliance } \\
\text { Bulletin (10 } \\
\text { Issues) }\end{array}$ & Hillsboro, WV & $\begin{array}{c}\text { National } \\
\text { Alliance }(1970)\end{array}$ & $\begin{array}{c}\text { White } \\
\text { Racial/Ethnic } \\
\text { Identity }\end{array}$ & $\begin{array}{c}\text { August } \\
2010- \\
\text { June } 2013\end{array}$ \\
\hline $\begin{array}{l}\text { American } \\
\text { Renaissance } \\
\text { (10 Issues) }\end{array}$ & Oakton, VA & $\begin{array}{l}\text { New Century } \\
\text { Foundation } \\
(1990)\end{array}$ & $\begin{array}{l}\text { Academic } \\
\text { Supremacy }\end{array}$ & $\begin{array}{c}\text { April } \\
2011- \\
\text { January } \\
2012\end{array}$ \\
\hline $\begin{array}{l}\text { American } \\
\text { Free Press } \\
\text { (10 Issues) }\end{array}$ & Washington, D.C. & $\begin{array}{c}\text { The Barnes } \\
\text { Review (1994) }\end{array}$ & Revisionist & $\begin{array}{c}\text { November } \\
2013- \\
\text { February } \\
2014\end{array}$ \\
\hline $\begin{array}{c}\text { Occidental } \\
\text { Quarterly (2 } \\
\text { Issues) }\end{array}$ & Atlanta, GA & $\begin{array}{l}\text { The Charles } \\
\text { Martel Society } \\
\text { (2001) }\end{array}$ & $\begin{array}{l}\text { Academic } \\
\text { Supremacy }\end{array}$ & $\begin{array}{c}\text { August } \\
2011- \\
\text { January } \\
2014\end{array}$ \\
\hline $\begin{array}{c}\text { First } \\
\text { Freedom (4 } \\
\text { Issues) }\end{array}$ & Silverhill, AL & $\begin{array}{c}\text { The League of } \\
\text { the South } \\
(1994)\end{array}$ & $\begin{array}{c}\text { Neo- } \\
\text { Confederate }\end{array}$ & $\begin{array}{c}\text { August } \\
2013- \\
\text { January } \\
2014\end{array}$ \\
\hline
\end{tabular}


The ideological foundations of the groups that distribute these publications are nearly identical. But their ideological approaches and positions do vary. The National Socialist Movement presents itself as a White civil right organization akin to the NAACP. The National Alliance stands itself on a foundation of the importance of a White European identity. Both the National Socialist Movement and the National Alliance adopt a National Socialist social and political ideology as their foundation. The Barnes Review is a historical revisionist and Holocaust denial organization and its American Free Press bills itslef as an alternative news source. As a Neo-Confederate group the League of the South rallies its supporters around the idea of Southern secession and the creation of an independent Southern Confederacy. The term "academic racism" is the term used by the Southern Poverty Law Center to describe both The Charles Martel Society and the New Century Foundation. These organizations rely heavily on the credentialism and portrayed scholarly authority of their members in their discussion of White ethnic/racial superiority.

Using qualitative content analysis, as described in methodology texts such as “The Basics of Social Research" by Earl Babbie (2005) and Berg \& Lune's "Qualitative Research Methods for the Social Sciences" (2004), line by line coding of the 44 White Nationalist newsletters was performed in order to identify both manifest and latent content within the articles. The identification of the frames of communication was paramount to a successful project and this type of analysis allowed for a deeper and richer examination of the text in hopes of identifying recurring themes. Drawing on the 
work done and the connections drawn by Rebecca S. Katz \& Joey Bailey (2000), Mitch Berbrier (2000), Leonard Zeskind (2009), and Kathleen Blee \& Kimberly Creasap (2010) I felt justified in my decision to begin looking at and for themes relating to nationalism, immigration, and White Nationalist defense of White Americans.

Drawing heavily on the work of Abby Ferber and Jessie Daniels I used a two-step process for my analysis. The first step is to read the content for the purpose of gaining a general idea of the words, phrases, images and themes present. This is similar to the "open coding" used in a grounded theory approach to qualitative analysis (Babbie, 2013). It also serves as a guide for the second step in the process which involves identifying a unit of analysis; categorizing emergent themes identified in the first step; capturing these themes; analyzing the coded content and finally explanation of findings, which I will cover in a later chapter (Daniels, 1997).

My unit of analysis was sentences. After reading the first few newsletters I came to the conclusion that anything smaller would create far too many codes that would only be collapsed as I moved through the steps of analysis. Anything larger and I felt that important distinctions between themes would be lost when lumped together with others. As mentioned previously I had a fairly clear idea of what I was looking for before starting my analysis though I was unsure how much of what I was looking for I'd actually find. This made the development of code categories fairly easy. Though I was sure to remain flexible enough to allow for the addition of new categories and codes as the analysis progressed. Ultimately 14 codes were developed. They were organized in to five code categories, each containing interrelated codes. A sixth miscellaneous code category was 
created for the purpose of being able to later discuss all codes and respective code categories.

\begin{tabular}{|c|c|c|c|c|c|c|}
\hline \multicolumn{2}{|c|}{$\frac{\text { Code Category: }}{\text { Racist }}$} & \multicolumn{3}{|c|}{$\frac{\text { Code Category: }}{\text { Anti-White }}$} & \multicolumn{2}{|c|}{$\begin{array}{l}\text { Code Category: } \\
\text { Problem Solver }\end{array}$} \\
\hline$\frac{\text { Code: }}{\text { Anti-Semitism }}$ & $\begin{array}{c}\text { Code: } \\
\text { Traditional } \\
\text { Supremacy }\end{array}$ & $\frac{\text { Code: }}{\text { Anti-White }}$ & $\frac{\text { Code: }}{\text { Pro-Minority }}$ & $\begin{array}{c}\frac{\text { Code: }}{\mathrm{WN}} \\
\text { Victimization }\end{array}$ & $\begin{array}{l}\text { Code: } \\
\text { WPM } \\
\text { Political }\end{array}$ & $\frac{\text { Code: }}{\text { Defender }}$ \\
\hline $\begin{array}{l}\text { Statements } \\
\text { referencing } \\
\text { traditional anti- } \\
\text { Semitic } \\
\text { statements. } \\
\text { Discussion of } \\
\text { Jewish } \\
\text { Conspiracy, } \\
\text { ZOG, } \\
\text { Holocaust } \\
\text { denial. }\end{array}$ & $\begin{array}{l}\text { Statements } \\
\text { referencing } \\
\text { minorities being } \\
\text { lesser, prone to } \\
\text { crime, on welfare, } \\
\text { genetically and } \\
\text { biologically } \\
\text { inferior. White's } \\
\text { are still better } \\
\text { solely because } \\
\text { they are White. }\end{array}$ & $\begin{array}{l}\text { Statements } \\
\text { referencing activity } \\
\text { that doesn't actively } \\
\text { work toward the } \\
\text { empowerment, } \\
\text { advancement, } \\
\text { maintenance or } \\
\text { reaquisition of White } \\
\text { racial dominance. }\end{array}$ & $\begin{array}{l}\text { Statements referencing } \\
\text { political policies/ } \\
\text { items/practices/ programs as } \\
\text { failing/undermining White } \\
\text { supremacy/ position as a } \\
\text { result of "Pro-Minority" } \\
\text { action. }\end{array}$ & $\begin{array}{l}\text { Statements } \\
\text { referencing WN } \\
\text { members being } \\
\text { targeted for their } \\
\text { belief and } \\
\text { affiliation. }\end{array}$ & $\begin{array}{l}\text { Statements } \\
\text { referencing } \\
\text { WN political } \\
\text { solutions, } \\
\text { party } \\
\text { platforms or } \\
3^{\text {rd }} \text { party } \\
\text { organizations. }\end{array}$ & $\begin{array}{l}\text { Statements } \\
\text { referencing } \\
\text { the defense } \\
\text { of the } \\
\text { White race, } \\
\text { European } \\
\text { ethnicity, } \\
\text { or culture. }\end{array}$ \\
\hline \multicolumn{2}{|c|}{$\frac{\text { Code Category: }}{\text { White Pride }}$} & \multicolumn{3}{|c|}{$\frac{\text { Code Category: }}{\text { Political }}$} & \multicolumn{2}{|c|}{$\frac{\text { Code Category: }}{\text { Miscellaneous }}$} \\
\hline $\begin{array}{l}\text { Code: } \\
\text { WPM } \\
\text { Historical }\end{array}$ & White $\frac{\text { Code: }}{\text { Nationalism }}$ & $\begin{array}{c}\text { Code: } \\
\text { Immigration }\end{array}$ & $\begin{array}{c}\text { Code: } \\
\text { Political Failure }\end{array}$ & $\begin{array}{l}\text { Code: } \\
\text { Right-Wing } \\
\text { Political }\end{array}$ & \begin{tabular}{l|} 
Code: \\
Facts \& \\
Stats
\end{tabular} & $\frac{\text { Code: }}{\text { Conspiracy }}$ \\
\hline $\begin{array}{l}\text { Statements } \\
\text { referencing the } \\
\text { celebration of } \\
\text { "European" and } \\
\text { "Aryan" people } \\
\text { and culture } \\
\text { throughout } \\
\text { history. The } \\
\text { idea that only } \\
\text { "White" } \\
\text { cultures and } \\
\text { civilizations } \\
\text { have } \\
\text { contributed to } \\
\text { the knowledge, } \\
\text { class, culture } \\
\text { and well-being } \\
\text { of humanity. }\end{array}$ & $\begin{array}{l}\text { Statements } \\
\text { referencing a } \\
\text { Racial/Ethnic } \\
\text { national identity. } \\
\text { America is } \\
\text { "supposed" to be a } \\
\text { White nation and } \\
\text { pride should be } \\
\text { taken in that. } \\
\text { White Pride, White } \\
\text { Power, White } \\
\text { Superiority, White } \\
\text { Culture. }\end{array}$ & $\begin{array}{l}\text { Statements } \\
\text { referencing illegal } \\
\text { immigration, amnesty, } \\
\text { immigration reform, } \\
\text { the negative effect of } \\
\text { immigration and/or } \\
\text { the importance of } \\
\text { stopping immigration. }\end{array}$ & $\begin{array}{l}\text { Statements referencing WN's } \\
\text { point of view that the } \\
\text { government is failing White } \\
\text { America and White } \\
\text { Americans. }\end{array}$ & $\begin{array}{l}\text { Statements } \\
\text { referencing } \\
\text { mainstream } \\
\text { Right-Wing } \\
\text { political } \\
\text { discourse. } \\
\text { Statements that } \\
\text { are nearly } \\
\text { indistinguishable } \\
\text { from those made } \\
\text { my mainstream } \\
\text { political figures. }\end{array}$ & $\begin{array}{l}\text { Statements } \\
\text { referencing } \\
\text { statistics } \\
\text { and/or } \\
\text { reports of } \\
\text { information } \\
\text { used in a } \\
\text { way that } \\
\text { supports a } \\
\text { WN } \\
\text { ideology. }\end{array}$ & $\begin{array}{l}\text { Statements } \\
\text { referencing } \\
\text { various } \\
\text { conspiratoria } \\
1 \text { beliefs } \\
\text { other than } \\
\text { those of a } \\
\text { traditionally } \\
\text { anti-Semitic } \\
\text { nature. }\end{array}$ \\
\hline
\end{tabular}

The first category is RACIST. This category includes content coded as traditional supremacy and anti-Semitic. I define traditional supremacy as, "Overtly racist content that focuses on genetic, biological, or evolutionary differences between White and nonWhites." Use of words traditionally identified as "racial epithets" were also coded as traditional supremacy. Anti-Semitic was defined as "hostility toward or discrimination against Jews as a religious, ethnic, or racial group (http://www.merriamwebster.com/dictionary/anti-semitism)." Statements that imply, relate or discuss any type 
of "global Jewish conspiracy”, “Zionist Occupation Government (ZOG)” or Holocaust denial were also coded as anti-Semitic and included in the RACIST category.

The second category that was developed was ANTI-WHITE. Codes in this category were primarily made up of instances of "victim ideology" presented by White Nationalist groups. Mitch Berbrier (2000) notes that "contemporary White supremacists engage in a "new racist" discourse that is interpreted as managing impression and constructing images;... images of Whites and especially White males as victims are rampant (175)." This category consists of three codes: Pro-Minority, Anti-White, and White Nationalist Victimization. Content that was coded as Pro-Minority was that content which discussed or presented examples of non-White minority groups in America being given favor or preference over White Americans. Examples of this include references to government programs that are only available to minorities, academic or social programs that minority status is a requisite of and "minority pride" organizations that exist when "White pride" organizations are criticized. Anti-White as a code was any content that discussed activity that didn't actively work toward the empowerment, advancement, maintenance or reacquisition of White racial dominance is seen as "antiWhite." These can be governmental policies, inter-racial marriage, same-sex marriage, desegregation, Anti-Racist group activity. But also passivity. If a person isn't actively working on promotion of the White Nationalist agenda then they are anti-White. Concepts like "White-genocide", White racial/ethnic minority population density, abortions offered to White women, and/or failure to "appropriately" respond to crimes against Whites are some examples of items coded as Anti-White. White Nationalist 
Victimization became a unique code after examples of White Nationalist groups being specifically targeted by governmental structures, private citizens or anti-racist groups were noted in multiple newsletters. This particular code straddles two categories, AntiWhite and Problem Solver (which I will discuss next). White Nationalist often see themselves as defenders of the White race. The activities they take part in are part of a larger agenda and goal; protecting the sanctity and future of the White race. Content coded as White Nationalist Victimization was that which portrayed White Nationalist groups or individuals be targeted for violence, discrimination, or character assault due to their affiliation with the White Nationalist movement. Not only were they victims because of the color of their skin but also because of the content of their character and the activities they engage in and affiliations they hold.

These activities and affiliations led to the formation of a third coding category I called Problem Solver. The codes included here were Defender and White Power Movement Political (WPMP). The "About the Party" section of the National Socialist Movement (NSM) website (http://www.nsm88.org/aboutus.html) clearly states the mission and intent of the NSM:

The NSM's core beliefs include defending the rights of white people everywhere, preservation of our European culture and heritage, strengthening family values, economic self-sufficiency, reform of illegal immigration policies, immediate withdrawal of our national military from an illegal Middle Eastern occupation, and promotion of White separation.

This statement illustrates that the motivation for the creation of the Problem Solver category. The NSM website also has listed on its home page two quotes. The first, "Putting Family, Race and Nation First while Fighting to Secure American Jobs, 
Manufacturing \& Innovation" highlights the organizations focus defending that which it believes to be under attack, the White family, the White race and the White nation. The second quote, "America's Premier White Civil Rights Organization - Fighting for White Civil Rights" illustrates the NSM position not as a "hate" group but as a "help" group. They attempt to position themselves as a friend to and supporter of the everyman, the working class, the ideal American. As long as you're White and of European ancestral lineage. This theme of Defender was constant across all White Nationalist publications regardless of affiliation or intended audience. This defense often came in the form of political plan or policies that would save White America and for this reason the White Power Movement Political code was created. Discussions of political goals, racially motivated polices, political action or organization and discussion of White Nationalist political ideology were coded as WPMP. White Nationalists feel they have identified the source of all of White America's trouble and they have the answers.

The wellspring from which a majority of threats, dangers and problems White Americans suffer at the hands of is the current American political machine. Themes relating to various political grievances, distrust, failure and ineptitude were common and resulted in three codes that were categorized as Political codes. Political Failure became a code as I began to notice a near constant discussion of the ways the current political framework of America was failing its White citizens. Political Failure often co-occurs with various Anti-White codes as an example of anti-White activity and Problem Solver codes as an antecedent highlight the problem that needs to be solved. Gardiner (2005) writes "I am comfortable making the claim that immigration is by far the most important 
policy issue on the White Nationalist agenda (66)" and as such I included the code Immigration in the my analysis as part of the Political category. As mentioned previously much of the rebranding and mainstreaming of White Nationalist ideology is born of a desire to appeal to a greater politically right-leaning audience (Gardiner 2005) and as a result of this I developed a code for Right-wing Political content. This was used to identify statements that were either borrowed directly from conservative politicians, pundits and groups or could be thought to have come from such a source with the removal of contextual markers. One way to think about this code is that if the statement could be imagined being said by or written for a mainstream, socially accepted, political conservative on network television it was coded as Right-wing Political.

When writing on the subject of a victim ideology claimed by many White Nationalists Berbrier (2000) lists five sections of analysis for this "contemporary victim ideology" (179). His third section "Excluded from pride; stigmatized and shamed" was the basis for my fourth category White Pride. Two recurring themes were coded under this category; White Nationalism and Historical White Power. White Nationalism referred to instances when pride in, support of, loyalty to, and/or love for the White race was expressed. Statements made about the current well-being or success of Whites over non-Whites and the failures of non-Whites as compared to Whites was coded as White Nationalism as well. Historical White Power was more difficult because of the gray area that exists between Traditional Supremacy, Defender and White Nationalism. Ultimately it became references made to the historical social, economic, educational, and governmental or class successes of the White race and failures of non-Whites. Examples 
include discussions of advancements made in culture, art, science, invention, society building, and or economics by White Americans or ethnically identified Western/Northern Europeans.

In revisiting his 1995 work The Racist Mind Raphael Ezekiel (2002) discusses four truisms on which organized White nationalism rests, one of which is "society's surface conceals conspiracy (67)." For this reason I began my analysis thinking that I would find conspiratorial thinking or ideology as a recurring theme. It was not long before this thought came to bear and a category and code for Conspiracy was developed. Much of the content that was coded as Conspiracy overlapped with the Anti-Semitism and Traditional Supremacy codes but was different enough in its statement, usage and meaning that I kept the codes separate.

A final code that was developed was what I called Facts and Stats. This code wasn't set within a particular category because I found that the authors of these publications would cite studies, report crime or census data and sometimes reference pseudo-scholarly sources in an attempt to lend credibility to their otherwise bigoted or racially/ethnically biased statements or theories. I noticed this trend early on in my coding and decided I would add it as a code, knowing that I might throw it out later if I found it was just a trend found in a couple of publications. As I continued to code I occurred in all six publications types.

The sheer volume of WN content on the internet is astounding. Jessie Daniels (2009) cites a 2003 report from the Council of Europe (COE) that suggests 2,500 of nearly 4,000 racist websites on the internet originate in the United States (Daniels 2009, 
5). This makes any attempt at a representative sample of $\mathrm{WN}$ publications almost impossible. While this can be seen as a limitation I feel very strongly that my efforts to address the limitation and collect content that was both relevant and reasonably representative of WN belief and ideology were successful. Given more time and resources, a collection of greater depth and breadth could be collected and analyzed. That being said I am confident that the practices employed during this project are academically appropriate and methodologically sound.

A key strength of choosing to do qualitative content analysis was that it allowed me to focus on the ways that those frames of communication were constructed. There was no concern paid to social desirability bias, or over/misrepresentation of belief or ideology as a means of posturing. These types of concerns often arise in other forms of qualitative research but are rarely if ever present in content analysis. A strength of content analysis also comes from the fact that there is almost no hesitation, by WN's, to express overtly racist ideologies in the publications that they produce because they see them as a safe haven of hate far from the eyes of a disapproving cultural majority (Daniels 1997).

Having previously discussed the motivation for this project, the previous research, a variety of theoretical perspectives that informed its development and now the methodological approach I will now move on to a presentation of my findings. 


\section{Chapter 5 \\ FINDINGS:}

Having previously discussed the methodological and analytic approach I took in examining White Nationalist publications I will now present the findings of this analysis. Each of the six publications will be discussed separately and a final section highlighting similarities among all the publications will be presented prior to moving on to a more thorough discussion and suggestions for future research.

\section{GENERAL FINDINGS:}

Table 3: Summary of Total Applied Codes, Code Category Prevalence, Most Often Occurring Code and Sampled Publication Date Range

\begin{tabular}{|c|c|c|c|c|}
\hline $\begin{array}{c}\text { Total } \\
\text { Codes } \\
\text { Applied }\end{array}$ & $\begin{array}{c}\text { Most } \\
\text { Prevalent } \\
\text { Code } \\
\text { Category }\end{array}$ & $\begin{array}{c}\mathbf{2}^{\text {nd }} \text { Most } \\
\text { Prevalent } \\
\text { Code } \\
\text { Category }\end{array}$ & $\begin{array}{c}\text { Most Often } \\
\text { Occurring } \\
\text { Code }\end{array}$ & $\begin{array}{c}\text { Date Range of } \\
\text { Collected Sample }\end{array}$ \\
\hline 1209 & $\begin{array}{c}\text { Anti- } \\
\text { White } \\
(28.29 \%)\end{array}$ & $\begin{array}{c}\text { Political } \\
(26.88 \%)\end{array}$ & $\begin{array}{c}\text { Anti-White } \\
\text { occurred more } \\
\text { often than } \\
\text { several entire } \\
\text { code categories) }\end{array}$ & $\begin{array}{c}\text { April 2009- } \\
\text { February 2014 }\end{array}$ \\
\hline
\end{tabular}

Forty-four newsletters were analyzed for this project, resulting in the identification of 769 excerpts and the application of codes created during that process 1209 times. As would be expected the aggregate percentages of code category occurrence was nearly identical to the occurrences found in each of the six publications. The Anti-White category codes making up $28.29 \%$, Political codes $26.88 \%$, Racist codes 13.4\%, Problem Solver 11.91\%, White Pride 8.6\%, with Facts \& Stats and Conspiracy making up the last $6.92 \%$. 
What frames of communication are used by White Nationalists for the purposes of recruitment, indoctrination and the strengthening of existing beliefs? Ultimately, I believe that these findings speak directly to this research question and make a great deal of progress toward answering it.

The frames of communication used are those of an anti-White political and social agenda. The government of not only the United States but of all historically Aryan countries is failing in its duty to protect the status quo and maintain a racially White, ethnically European majority. Though certainly a key issue for White Nationalist groups, immigration was not found to be the most significant theme presented or discussed. For this reason I find myself disagreeing with Gardiner's 2005 statement that “immigration is by far the most important policy issue on the white nationalist agenda (66)." These frames of communication also stand in contrast to those discussed by Ferber (1998) and Daniels (1997) but the frames in thought have not. This is supported by the continued prevalence of traditionally racist thought and anti-Semitic conspiratorial belief used to explain the social, political and economic plight of the "Aryan" people across the world. This research focuses on the creator and distributor of a White Nationalist message, not the consumer of that message. As such it is beyond the ability of the research, the analysis and the resultant findings to make any definitive commentary on how the frames of communication are received. Despite this, I am confident that my analysis, when combined with knowledge gained through the exploration of previous literature, does address each part of my research question. 


\section{Recruitment Frames:}

For the purposes of recruitment and the initial mobilization of non-affiliated actors frame extension strategic framing processes are most often used. As mentioned previously Benford and Snow (2005) discuss frames being "developed and deployed to achieve a specific purpose (624)" and often that purpose is recruitment. White Nationalist groups deploy these frames against a large group of individuals in hopes of gaining their attention and piquing their interest; in much the same way militia group message presentation is discussed by Kenneth Stearns. These frames of communication focus on issues the movement actors presume are important to their audience. They focus on the failure of the US political system; they co-opt a mainstream social and political message and attempt to call attention to the injustice that Whites are forced to face. These appear to be used most regularly in this manner and for these purposes. The frames may often be nearly void of any overt racism or bias and nearly identical to those found in mainstream discourse. The difference is contextual. When the entirety of an article, newsletter or publication is examined or when a little bit of critical thinking is applied the racism and bias comes out. White Nationalists identify the themes present in mainstream discourse, repackage, regurgitate, and restate them with a biased twist at the end meant to make the reader ask questions about the topic. Questions that the White Nationalist actors hope to provide an answer to, answer steeped in racism.

\section{Indoctrination Frames:}

After initial exposure and as newly approached or recruited movement actors begun to transition through this "funnel" the frames of communication can be changed by 
the movement. Though new frames aren't necessarily needed, as individuals' frames in thought, once developed, often affect how the same frames of communication are received. The frame amplification processes used by White Nationalist groups in this study are very similar to those discussed by Mitch Berbrier in his 1998 analysis of what he refers to as "new racist" rhetoric.

In an attempt to proselytize to new movement actors White Nationalists transform their message in to one of White pride, historical European social superiority and accomplishment and the importance of ethnic identity. A strategy employed across all publications was to present "hypocrisy" in the stigma attached to European ethnic or White racial pride that is not similarly associated with minority pride.

\section{Maintenance Frames:}

Ideological maintenance requires different frames of communication than those used for recruitment or indoctrination, though framing processes are likely fluid in all stages of mobilization. The processes found most often utilized in apparent attempts at ideological maintenance were strategic framing in response to counter-framing by opponents, bystanders and the media, and discursive frame amplification.

Responses by White Nationalists to oppositional counter-framing often take the form of collective action frames that focus on discourse surrounding the White Nationalist response to anti-White policies or the adoption of victim ideology. Movement actors portray themselves as suffering as a result of their ideology. They also present a message that stands in opposition to that presented by the dominant culture as to what their intended purpose is and what their ideology truly means for themselves and 
others.

Where strategic frame amplification exaggerates the importance of existing beliefs or ideas and the frames are deployed against prospective movement actors, discursive frame amplification overemphasizes the relative importance of events and issues and is seen in the communication, written or verbal, between movement actors and at or surrounding movement events (Benford and Snow, 2000). These amplified frames often presented in discussion of the need for White Nationalist groups as defenders of the White race and the importance of maintaining a European ethnic identity. The tendencies for White Nationalist groups, in their writing and discussion, to embellish "attacks" against them, exaggerate the cultural and historical significance of European culture, discount the contributions of minority culture and champion themselves as the necessary savior of the White race all serve as examples of these discursive frame amplification processes.

NATIONAL SOCIALIST MOVEMENT:

\begin{tabular}{|l|l|l|l|}
\hline \multicolumn{2}{|l|}{$\begin{array}{l}\text { Table 4: Summary of National Socialist Movement Affiliation, } \\
\text { Position, Highest \% Code Category \& Sample Date Range }\end{array}$} \\
\hline $\begin{array}{l}\text { Organizational } \\
\text { Affiliation }\end{array}$ & $\begin{array}{l}\text { Organizational } \\
\text { Position }\end{array}$ & $\begin{array}{l}\text { Highest \% } \\
\text { Code } \\
\text { Category }\end{array}$ & $\begin{array}{l}\text { Date Range of } \\
\text { Collected Sample }\end{array}$ \\
\hline $\begin{array}{l}\text { National } \\
\text { Socialist } \\
\text { Movement }\end{array}$ & $\begin{array}{l}\text { White Civil } \\
\text { Rights }\end{array}$ & $\begin{array}{l}\text { Political } \\
(27.31 \%)\end{array}$ & $\begin{array}{l}\text { April 2009- } \\
\text { September 2013 }\end{array}$ \\
\hline
\end{tabular}

The National Socialist Movement (NSM) publications were by far the most heavily coded. Through the coding of eight NSM publications written between 2009 and 
2013 the codes created for this analysis were applied a total of 509 times. This is not to say that 509 separate items were coded as many statements or sections had multiple codes attached to them. The NSM bills itself as a White Civil Right organization and a political party that attempts to serve the interests of White Americans.

"The NSM is a White Civil Rights Movement that adheres to political activism, and legal means to restore America to its former glory." (NSM Newsletter Summer/Fall 2010)

Support for these claims can be seen in the content of their publication and the manner in which their ideology is framed and presented. Codes within the "Political" category were the most often occurring at $27.3 \%$ of all coded content. More than $20 \%$ of the coded content fell in the "Anti-White" category. With the codes from these two categories being applied to nearly half of the NSM material coded they appear to be conveying a message that the White race is under attack and at risk of extinction in America and the government is not only failing to protect the White race but in many ways serving as a willing agent of its destruction. The following quote from the Spring/Summer 2013 NSM Newsletter demonstrates this point appropriately:

"The Aryan Race has been denied self-determination through the actions of both internal and external forces, these forces operating out of hatred and/or self-interest to inhibit the social and economic health of Aryan families worldwide, with the ultimate goal being the extinction of our kind through genocidal social, political, and economic programs."

The NSM bills itself as the last line of defense for White Americans in a world that seeks to eradicate the White race through race-mixing, multiculturalism, forced integration and a pro-minority/anti-white politics. They see these as problems that plague White America and put its future at risk. In response, they have adopted National 
Socialism as a solution to these threats. They see themselves and others like them as the standard bearer for White equality and a future America that is racially homogenous. Codes within the "Problem Solver" category accounted for $17 \%$ the coded material.

"National Socialism represents the most sound means of assuring the biological and cultural rejuvenation and progression of the White, or Aryan race." (NSM Newsletter Spring/Summer 2013)

Having identified the problems facing White America, developed solutions and built a political platform from which to broadcast their message, the NSM also encourage White Americans to take pride in their heritage and culture. They broadcast a message of historical and modern Aryan dominance, intellectual prowess and social superiority. In many ways it seems that they've moved away from genetic and biological support for their position on racial superiority and have adopted an ideology that seems to say "we deserve to be in charge because historically we always have been." The White Power Movement Historical and White Nationalism codes that make up the White Pride category accounted for nearly $13 \%$ of the coded content. The following quote illustrates the sense of pride that members of the NSM have in their heritage and how this heritage should afford White Americans a privileged place in society:

"It is our mental character that makes us Aryan -- our willingness for selfless service, our willingness to die for a comrade...our love, passion, and our honor. We are the noblest of races, and also the most superior. But we do not just have technological superiority over the other races, it's our souls, and our values that make us Aryan." (NSM Newsletter Winter/Spring 2012)

As one will notice from the findings discussed so far the frames of communication employed by the NSM are not the same as those seen in decades gone by. 
The supremacy is certainly still there. But it's presented in a softer, more palatable way. The message has taken a much more nationalistic tone and less of a racial superiority position. The NSM fruit hasn't fallen that far from the Third Reich tree, though. Following up many of the statements about political failure, anti-White attacks or White racial defense are pronouncements that were coded as "Anti-Semitic" or "Traditional Supremacy" and became the "Racist" category. In fact $12.97 \%$ of the coded content in the NSM newsletters fell in this category. Most often these statements were anti-Semitic and conspiratorial in nature, as the following quote illustrates:

"We as National Socialist must realize that our number one enemy is the Jew. All of the other inferior races that are in our country are not intelligent enough to direct the destruction of our race. They are just pawns in the Jews evil game of financial and social chess." (NSM Newsletter Winter/Spring 2012)

As previously mentioned the NSM publications had the greatest amount of coded material. These publications also had the widest array of content. The foundation of this content was shown to be based in the same frames in thought as previous literature has found: racist, supremacist, bigoted and segregationist. Only the frames of communication have been adapted. Next, I will review the findings of another US based National Socialist organization, the National Alliance. 


\section{NATIONAL ALLIANCE:}

\section{Table 5: Summary of National Alliance Affiliation, Position, Highest \% Code Category \& Sample Date Range}

\begin{tabular}{|l|l|l|l|}
\hline $\begin{array}{l}\text { Organizational } \\
\text { Affiliation }\end{array}$ & $\begin{array}{l}\text { Organizational } \\
\text { Position }\end{array}$ & $\begin{array}{l}\text { Highest \% } \\
\text { Code } \\
\text { Category }\end{array}$ & $\begin{array}{l}\text { Date } \\
\text { Range of } \\
\text { Collected } \\
\text { Sample }\end{array}$ \\
\hline $\begin{array}{l}\text { National } \\
\text { Alliance }\end{array}$ & $\begin{array}{l}\text { White } \\
\text { Racial/Ethnic } \\
\text { Identity }\end{array}$ & $\begin{array}{l}\text { Problem } \\
\text { Solver } \\
(25.98 \%)\end{array}$ & $\begin{array}{l}\text { August } \\
\text { Ju10- } \\
\text { June } \\
2013\end{array}$ \\
\hline
\end{tabular}

The National Alliance is another National Socialist group based in the United

States. Though they differ in structure and organization, they are fundamentally the same as the NSM on an ideological basis. The findings of this analysis bear witness to that with many of the same codes and categories being the predominantly reoccurring content in the newsletters that were coded and analyzed.

The codes developed for this analysis were applied 127 times to content from 10 National Alliance newsletters written between 2010 and 2013. Every code was applied to content at least once with multiple codes being applied to the same section of content, creating numerous instances of code co-occurrence.

As with the NSM newsletters the codes making up the "Political" category were found to be present in much greater quantity than most other codes though not enough to result in "Political" being the most present code category. Though close, the code category "Problem Solver" was the most often coded at $25.98 \%$, with "Political" at $24.41 \%$. The co-occurrence of codes within this category continued to occur but not in 
the same frequency as with other publications. White Power Movement Political content tended to occur much more on its own and was very straight forward in its message:

"But Our Cause is far from accomplishing even its most immediate, concrete goal: the securing of a homeland for White people." (National Alliance newsletter, September 2011)

Content coded as Defender also was found to be presented in a very direct manner and often by itself: "We must fight for the security and survival of our people." (National Alliance newsletter, March 2011)

The code category "Political" contains three codes, of which Right-Wing Political was the second least occurring code across all of the National Alliance newsletters. Despite the rare occurrence of this particular code, the code category accounted for nearly $26 \%$ of the total coded content found in the National Alliance newsletters. The codes Immigration and Political Failure occurred quite often, usually together.

"And, incidentally, no White racialist will deny that the federal government - as shown by its incompetence and fumbling with the immigration issue in the Southwest - doesn't give a damn about the rights of American citizens.” (National Alliance newsletter July/August 2011)

Where the NSM bills itself as White Civil Rights group and attempts to call attention to, according to them, "White-genocide" in America, the National Alliance does not take this same position and as such presents their message in a much different way. The Anti-White code category only accounted for $17.32 \%$ of the coded National Alliance content. Much of this was content coded as Anti-White. Pro-Minority and White Nationalist Victimization were coded much more infrequently. The Anti-White code occurred both by itself and in conjunction with various other codes as the following quote, coded Anti-White and Pro-Minority shows: 
"The men in power, of whatever race or creed, are united on the idea that, while it is acceptable for individuals to seek their own destiny as they see fit, the White race has no such right." (National Alliance newsletter March, 2011)

The code category Racist, which accounted for $12.6 \%$ of the coded content, contained codes for Anti-Semitic content and Traditional Supremacy. As mentioned previously it became clear that while anti-Semitism is a traditionally held belief by White Nationalists regardless of group affiliation the distinction and usage of traditionally supremacist ideologies and frames of communication was great enough that the creation of two codes was necessary. These codes occurred together and separately, though AntiSemitic content co-occurred most often with the Conspiracy code. The following quotes illustrate how these codes were similar and different, and as such necessitated unique codes.

"But, best of all...no non-Whites on our turf. No race-mixing. No Jewish filth on television or in the movies. No young Whites worshipping nonWhite music stars or non-White athletes." (National Alliance newsletter, September 2011)

This quote presents a more standard traditionally supremacist frame when discussing the Jews and non-White minorities.

"What does the attack on Pearl Harbor, the firebombing of Dresden, the wars in Afghanistan and Iraq, and the methodical assassination of Libyan leader Moammar Gadhafi all have in common) Answer: They all demonstrate that the Jewish-dominated U.S. government is not afraid to kill people or allow them to be killed, for Jewish interests." (National Alliance newsletter, October 2011)

Despite claims made by the National Alliance to support and encourage the development of a White ethnic/racial identity and a call to regain a connection with the White European heritage and custom the White Pride category only accounted for 
$11.02 \%$ of the coded material with the vast majority of the coded content being coded as White Nationalism. The following quote from the June 13 National Alliance newsletter shows how the organization uses calls for White Nationalism as a response to White Supremacist/Nationalist victimization.

"If we were to promote something called a "White Fest," we might attract two dozen people and then have rocks thrown at us by a hundred counterdemonstrators who would call us "haters....However, if we put on a European cultural festival we can attract thousands and even have the controlled media give us free publicity." (National Alliance newsletter June 2013)

The National Alliance and National Social Movement are the two leading NeoNazi organizations in America today. Both identify National Socialism as a political platform that serves the interests of White Americans. The other publications in this study differ from these in that they are produced, not for a specific ideological group or individual but instead, for the more general White Nationalist movement or persons who subscribe to White Nationalist beliefs.

\section{AMERICAN RENAISSANCE:}

Table 6: Summary of American Renaissance Affiliation, Position, Highest \% Code Category \& Sample Date Range

\begin{tabular}{|l|l|l|l|}
\hline $\begin{array}{l}\text { Organizational } \\
\text { Affiliation }\end{array}$ & $\begin{array}{l}\text { Organizational } \\
\text { Position }\end{array}$ & $\begin{array}{l}\text { Highest \% } \\
\text { Code } \\
\text { Category }\end{array}$ & $\begin{array}{l}\text { Date } \\
\text { Range of } \\
\text { Collected } \\
\text { Sample }\end{array}$ \\
\hline $\begin{array}{l}\text { New Century } \\
\text { Foundation }\end{array}$ & $\begin{array}{l}\text { Academic } \\
\text { Supremacy }\end{array}$ & $\begin{array}{l}\text { Anti-White } \\
\mathbf{( 3 9 . 8 8 \% )}\end{array}$ & $\begin{array}{l}\text { April } \\
\mathbf{2 0 1 1}- \\
\text { January } \\
\mathbf{2 0 1 2}\end{array}$ \\
\hline
\end{tabular}


The American Renaissance publications are a significant departure from the previously discussed Neo-Nazi publications of the NSM and National Alliance. The 10 issues of The American Renaissance newsletter that were analyzed resulted in 168 applied codes. Of these 168 applied codes, nearly $40 \%$ fell within the Anti-White code category. This is nearly twice the percentage of codes within this category for either the NSM or National Alliance. The ways in which the American Renaissance frames their message and claims of anti-White activity among non-White groups and the government is also slightly different.

"At the same time, the average MCAT (Medical College Admission Test) scores of black and Hispanic students enrolled at Harvard Medical School were 100 points (approximately one standard deviation) below the average score of Whites who were rejected by all American medical schools." (American Renaissance newsletter May 2011)

The above quote also illustrates the first time that the presence of the Fact \& Stats code becomes common place. While there was a significant gap between the most prevalent code category - Anti-White — and the next most_-Political_-39.88\% and $22.02 \%$ respectively, the code Facts \& Stats appeared a rather surprising $13.69 \%$ in the total coded content, but more about that shortly.

Despite not taking a definitive political position or offering much in the way of “problem-solving” The American Renaissance does frame a significant amount of its message as a critique of and response to US immigration policy, political failure and regurgitation of right-wing political punditry. Of these three issues immigration is certainly at the top of the list, as the following quotes demonstrate.

"immigration is killing the entire United States" (American Renaissance newsletter, April 2011) 
"A recent report by the Center for Immigration Studies (C IS) using 20 I 0 census data found that immigrant households with children are using more welfare than US natives." (American Renaissance, May 2011)

Here again we have content identified as having multiple appropriate codes applied to it. One of which is the Facts and Stats code in reference to the "recent report by the Center for Immigration Studies." It should be noted that in many cases the information reported as being from research or as statistical facts often come from rightwing groups such as the CIS, whose founder knowingly associated and followed very closely with White Nationalist groups, Holocaust deniers and anti-immigration groups in the United States (SPLC 2009). The editors and publishers of the American Renaissance rely very heavily on this type of quasi-legitimate "research" to provide credibility to their statements. As mentioned previously $13.69 \%$ of the analyzed content was fell under the Facts \& Stats code. These quotes illustrate the way that The American Renaissance supports their ideological framing with this information.

"If we could separate ourselves just from blacks, who are only about 13 percent of the population, half of all prison inmates, and even more than half of violent criminals would disappear." (American Renaissance September 2011)

"According to Department of Justice statistics blacks are seven to eight times more likely than whites to be incarcerated. (American Renaissance July 2011)

As with all the other publications included in this research the absence or infrequency of overtly racist themes, messages or frames of communication does not mean the individuals who write, edit and publish these newsletters are any less racist than they were 50 years ago. They just have found a way to veil their racism behind what they 
say is scientific data, historical precedence and modern theoretical understanding. The Traditional Supremacy code accounted for $14.88 \%$ of the total coded content for all 10 American Renaissance publications.

"Contemporary black-run societies, whether in Africa, Haiti, or in enclaves in the West are further evidence for race differences in intelligence and the ability to maintain civilization." (American Renaissance May 2011)

The American Renaissance newsletters certainly had some more prevalent codes but all in all the ideological framing and presentation was the same. The criticism of the US political climate, blaming economic turmoil on political failure and immigration policies and the adoption of a segregationist mentality using twisted statistics and questionable "facts" as support.

AMERICAN FREE PRESS:

Table 7: Summary of American Free Press Affiliation, Position, Highest \% Code Category \& Sample Date Range

\begin{tabular}{|l|l|l|l|}
\hline $\begin{array}{l}\text { Organizational } \\
\text { Affiliation }\end{array}$ & $\begin{array}{l}\text { Organizational } \\
\text { Position }\end{array}$ & $\begin{array}{l}\text { Highest \% } \\
\text { Code } \\
\text { Category }\end{array}$ & $\begin{array}{l}\text { Date Range } \\
\text { of Collected } \\
\text { Sample }\end{array}$ \\
\hline $\begin{array}{l}\text { The Barnes } \\
\text { Review }\end{array}$ & Revisionist & $\begin{array}{l}\text { Anti-White } \\
(32.47 \%)\end{array}$ & $\begin{array}{l}\text { November } \\
2013- \\
\text { February } \\
2014\end{array}$ \\
\hline
\end{tabular}

Ten issues of the American Free Press (AFP) newsletter were included in this research and 194 codes were applied. As has been seen with other publications, the majority of the coded content presented itself in the Anti-White and Political code categories, $32.47 \%$ and $29.38 \%$ respectively. Where we saw the code Facts and Stats 
make its presence felt in the American Renaissance newsletters, the Conspiracy code shined rather brightly when analyzing the AFP content with $16.49 \%$ of the total codes applied being that code.

The AFP pulls no punches in its discussion of what it sees is the destruction of the White race. As mentioned nearly $1 / 3$ of all the codes applied to AFP newsletters fell within the Anti-White coding category. A contributor to AFP writing under the name John Friend notes in the December 2013 issue, “Today's hatred of Whites will be tomorrow's large-scale victimization of whites." Another quote that demonstrates the AFP fear of White genocide is this:

"On Nov. 12, in an exclusive interview with AFP, California State University professor Kevin MacDonald detailed how White people's unselfish concern for others has reached pathological levels and is actually leading the White race down the path to destruction." (AFP November 25, 2013)

This previous quote serves as another example of using seemingly legitimate sources as a means of providing credibility to the ideological position that a White Nationalist group has taken. While Keven MacDonald is a professor at a California university it's important to note that he's received a lot of attention for maintaining associations with known White Supremacists and regularly contributing to and speaking for White Nationalist rallies, meetings and publications.

The Political code category, $29.38 \%$, was evenly distributed among the three codes within it, Immigration, Political Failure and Right-Wing Political. As with other publications attention is drawn to the failures of the current political system, though there were more examples of Right-Wing Political coded content. Often times these codes 
would co-occur and it would seem for a moment that one wasn't reading them from a known Supremacist publication.

"On the negative side, Obama said he intends to push a new immigration law, even if it means using an executive order to bypass Congress - a dangerous, unconstitutional plan that would legalize millions of illegal aliens hiding out in the United States." (AFP February 10, 2014)

"As if the learning environment in the U.S. public school system weren't already bad enough, the Obama administration has now made things much worse with new race-biased federal guidelines that will shield black and Latino students from disciplinary action for disruptive and violent behavior.” (AFP January 27, 2014)

The Conspiracy code was much more prevalent in the AFP publications than in others at $16.49 \%$ of the totally coded content. The types of conspiratorial ideology ranged from the JFK assassination to the 9/11 attacks. But they almost all had one thing in common, some connection to a more traditional, historically present belief in a global Jewish conspiracy.

"Independent researchers, investigative journalists and honest news outlets, such as AFP, have exposed 9-11 as an elaborate false-flag event planned, organized and executed by criminal elements within the American political and media establishment with direct ties to Israel." (AFP February 10, 2014)

Since the majority of conspiratorial content mentioned was directed toward a Jewish conspiracy, it's no surprise that the Racist code category, which accounted for nearly $11 \%$ of the content, was mostly made up of Anti-Semitic content. Often these two codes would co-occur in statements that seem to defy reason.

“AFP's own Victor Thorn, argue quite persuasively that Israel's intelligence agency, Mossad, working in conjunction with pro-Israeli criminals and propagandists embedded within the American political and media establishment, were the key players in the conspiracy to bring about the events of 9-11" (AFP January 20, 2014) 
The American Free Press presents itself as an alternative news source and stylizes its content in such a way that it is more appealing. They, like the American Renaissance, attempt to gain legitimacy and acceptance by using "proof" and "evidence" from seeming reputable sources.

"According to the Uniform Crime Reports for April 2011 to April 2012, blacks - who comprise $54 \%$ of the population of Atlanta - are responsible for $100 \%$ of homicides, $95 \%$ of rapes, $94 \%$ of robberies, $84 \%$ of aggravated assaults and 93\% of burglaries.” (AFP January 27, 2014)

Though they make every effort to twist the information they collect to fit their ideology and their message, as this quote shows. AFP's usage of presenting a case for a failing political and social climate that is attacking White's and working against them is a theme found in the previously presented content as well as the remaining content. With slight variations this trend continues.

\section{OCCIDENTAL QUARTERLY:}

Table 8: Summary of Occidental Quarterly Affiliation, Position, Highest \% Code Category \& Sample Date Range

\begin{tabular}{|l|l|l|l|}
\hline $\begin{array}{l}\text { Organizational } \\
\text { Affiliation }\end{array}$ & $\begin{array}{l}\text { Organizational } \\
\text { Position }\end{array}$ & $\begin{array}{l}\text { Highest \% } \\
\text { Code Category }\end{array}$ & $\begin{array}{l}\text { Date } \\
\text { Range of } \\
\text { Collected } \\
\text { Sample }\end{array}$ \\
\hline $\begin{array}{l}\text { The Charles Martel } \\
\text { Society }\end{array}$ & Academic Supremacy & $\begin{array}{l}\text { Anti-White } \\
(54.72 \%)\end{array}$ & $\begin{array}{l}\text { August } \\
\mathbf{2 0 1 1} \\
\text { January } \\
2014\end{array}$ \\
\hline
\end{tabular}

Only two issues of Occidental Quarterly (OQ) were analyzed for this research, resulting in 53 occurrences of the codes. The small number of issues coded was a result 
of various factors. OQ is a traditional quarterly publication printed four times a year.

This results in issues that are $100+$ pages in length. The "academically racist" position that $\mathrm{OQ}$ takes results in articles that are more historical perspectives and commentary than recruiting, reporting of "white-genocide" or planning for a racial holy war. Despite this, previously identified themes were still very present in OQ; namely that of the discussion of White victimization and anti-White sentiment in the United States. 54.72\% of the coded content was found to be in the Anti-White category, with the majority of individual codes being Anti-White. Discussion of White-genocide, anti-White governmental programs and fear of White racial extinction were the most common themes found in OQ newsletters.

In response to a report on the global population and percentages of various racial groups one contributor had this to say about his fear of a declining White population and an increasing non-White population, "Clearly, If the trend is left unchecked, our race will eventually disappear from the face of the planet (Occidental Quarterly, Fall 2013).” The following quote also demonstrates the ways that $\mathrm{OQ}$ attempts to legitimize itself and its opinions by attempting to take the "high road" and delineate between itself and other groups:

"As we come to grips with the ongoing assault on the White race, our goal should be to respond rationally rather than upsetting ourselves unnecessarily by our irrational thinking, and possibly taking action that could be self-defeating." (Occidental Quarterly Fall 2013)

Occidental Quarterly carried their approach of academic racism through to criticism and critique of the political climate in America as well. Nearly $19 \%$ of coded content was found to have the Political code category applied to it. Contributors to OQ 
most often sought to bring attention to the ways the government was not only failing White Americans but also actively working against their interests. "The Civil Rights Act of 1964 did the most damage by effectively making it illegal for Whites to advocate for White interests" (Occidental Quarterly Fall 2013), writes one contributor who only submits work under pseudonym.

As with other publications, OQ devotes a great deal of time to the discussion of immigration and its negative effect on White Americans, their safety, economic security, and class position. The negative effect of the failure of the U.S. immigration policy and the resultant deluge of undocumented immigrants to the U.S. is a recurrent theme in not only OQ but in all the publications reviewed during this project.

"All of us have had to flee the chaos of once stable ethnic neighborhoods to escape the violence and decay brought on by racial integration and illegal immigration." (Occidental Quarterly, Fall 2013)

The remaining codes and code categories were not found to be present in OQ in any significant way. Statements such as "Far from wrong or irrational, our desire to perpetuate our own kind is normal, healthy, and natural” (Occidental Quarterly, Fall 2013) and "Ok, so our objective is to help and protect our people - that huge and powerful evolutionary unit—and place them in control of their own destiny" (Occidental Quarterly, Summer 2011) illustrate that the writers and editors of Occidental quarterly hold strong traditionally segregationist/supremacist views and see themselves as being responsible for rallying support for the protection of a withering White race. 


\section{FIRST FREEDOM:}

\begin{tabular}{|l|l|l|l|}
\hline $\begin{array}{l}\text { Table 9: Summary of First Freedom Affiliation, Position, Highest \% } \\
\text { Code Category \& Sample Date Range }\end{array}$ \\
$\begin{array}{l}\text { Organizational } \\
\text { Affiliation }\end{array}$ & $\begin{array}{l}\text { Organizational } \\
\text { Position }\end{array}$ & $\begin{array}{l}\text { Highest \% } \\
\text { Code } \\
\text { Category }\end{array}$ & $\begin{array}{l}\text { Date } \\
\text { Range of } \\
\text { Collected } \\
\text { Sample }\end{array}$ \\
\hline $\begin{array}{l}\text { The League of the } \\
\text { South }\end{array}$ & Neo-Confederate & $\begin{array}{l}\text { Political } \\
(32.28 \%)\end{array}$ & $\begin{array}{l}\text { August } \\
2013- \\
\text { January } \\
2014\end{array}$ \\
\hline
\end{tabular}

The First Freedom newsletter is unique to this research project in that it is what would be considered a Neo-Confederate publication. Much of the content is produced by a single individual, the editor and lead writer Olaf Childress, while other content is submitted by or copied from writers for various other White Nationalist publications. Four issues of the First Freedom newsletter were analyzed resulting in 158 examples of thematically coded content. Mr. Childress is a staunch Neo-Confederate, a secessionist and very vocal in his segregationist ideology. These ideologies were made evident during the initial coding and upon later analysis of First Freedom. The Political and AntiWhite code categories were the most heavily present in First Freedom, 32.28\% and $30.38 \%$ respectively.

Mr. Childress takes issue with the United States government as a whole, regardless of political party. His perception of governmental failure is made very clear 
with statements such as:

"It is Congress that, if the Comprehensive Immigration Act of 2013 passes, must be seen as the enemy and traitor to our race, nation and Constitution, and the individual members dealt with accordingly." (First Freedom newsletter, October 2013)

Thought the previous quote mentions immigration, Mr. Childress is much more explicit on the issue of immigration and how he feels it is affecting America when he says:

"Also, in my opinion, the best way to secure our border is to establish machine gun nests all along it and order them manned by our military personnel who are presently stationed around the world." (First Freedom, August 2013)

The issue of anti-White policies and attacks along with the victimization and targeted attacking of White Nationalists is also something that First Freedom devotes a significant amount of time to covering. Of the $30.38 \%$ of coded material found in First Freedom the majority of it was coded as either Anti-White or White Nationalist Victimization. The following quote demonstrates these themes as well as the idea that non-White minority groups have privileges that Whites do not.

"The truly sad thing is that any other race, color, creed, sex, religion or ethnic group can meet openly anytime and anywhere; but a bunch of White guys intent only on the survival of their people has to be so secretive about its gatherings that those who want to be included don't get word." (First Freedom newsletter, September 2013)

Being that Mr. Childress uses First Freedom as a delivery system for his antigovernment, pro-Southern, neo-confederate ideology it should come as no surprise that the next most common themes were those associated with the Racist code category, accounting for nearly $19 \%$ of the coded content. Much of what is printed in First Freedom that was coded in this manner could be considered virulent anti-Semitism. It's hard to say the following quotes are anything but that. 
"The only solution to the World's Jewish Problem is the extermination of Judaism. All attempts from expulsion to quarantine have failed." (First Freedom newsletter, August 2013)

"Folks, what you have going on here is a bunch of subversive Whitehating Jews doing everything they can under the radar to turn us European Whites into a minority in our own lands" (First Freedom newsletter January 2014)

In addition to his traditional anti-Semitic ideologies and belief in a global Jewish conspiracy, Mr. Childress also makes regular references to Holocaust denial and is not the least bit skittish about informing his readers of these beliefs.

"Yet tests carried out at the so-called Auschwitz gas chambers found no residues which should have been present if that weren't a hoax." (First Freedom January 2014)

"Shortly after World War II, the thesis of "six million Jews" took on a new life. If you look back in history, Jewish lore is rife with multiple legends of mass Jewish slaughter. The story of "the Holocaust" (of World War II) that you hear so much about today is a variation on a very old theme. (First Freedom January 2014)

Though First Freedom is not quite so veiled in its discussion of White Nationalism it still serves as an example of how the messages, ideologies and viewpoints of these groups and individuals have adapted to an ever changing political and social landscape.

\section{SUMMARY:}

Contrary to statements made by Gardiner (2005) immigration does not appear to be the most important issue concerning White Nationalist groups today. Instead issues surrounding the perception of anti-White sentiment and practice within the United States and the failure of the US government to protect White Americans are the most prevalent issues in White Nationalist discourse. These findings also stand in sharp contrast to 
results presented in previous work done White Nationalist publications using content analysis, namely Daniels' work in 1997 and Ferber's work in 1998. Where they each found frames of communication focused on gender presentations, masculinity and heterosexism, my results show that these ideas and messages are still present but in much smaller instances and play a much less important role in the framing processes used to develop collective action frames for the movement.

Having presented my findings and briefly discussed how they relate to my research question I will next delve further in to the "so what" of these findings. After this discussion, I will address how New Social Movements Theory and the idea of Identity politics were used in the analysis and should continue to be applied to the understanding of White Nationalist group organization and ideological framing, as well as the limitations of the study. Lastly a brief exploration of further research will be presented. 


\section{CHAPTER 6 \\ DISCUSSION:}

As mentioned previously, White Nationalists are adapting their frames of communication in response an ever changing political and social landscape. Many individuals and organizations realize that the days of traditional White supremacy are past them. The ideologies born out of a time when genetic and inherently biological racial differences were thought to exist have had to change. That's not to say that some people don't still believe in them and will spend time trying to convince others of their scientific truth. The framing processes used have also had to adapt to this changing world. As the data suggests discussion of anti-White sentiment/action or racial extinction, a failing political machine, and uncontrolled illegal immigration now dominate White Nationalist discourse.

"Not only America, but Europe - the homeland of the White race - is facing mortal danger. It's life or death for the White race - the race that for all its faults created Western civilization." (First Freedom August 2013)

"I laughed because it was almost comical as to how far away the political establishment is from taking any concrete action that will help the longterm prospects of the White race, which is what I and many other White people care about most" (National Alliance newsletter September 2010)

"The Western World is being invaded — not by armed men, but by millions of penniless immigrants" (American Renaissance April 2011)

Each organization or camp of White Nationalist thought, which might approach these issues differently and offer a variety of solutions or no solution at all, sees the importance of framing their ideology and presenting their message in a way that makes it more palatable to the uninitiated listener. The writers, editors and contributors for these 
publications all have at least one thing in common, they want to attract the attention of enough like-minded individuals that they might gain social and political legitimacy in order to effect some change on society. They want to create a movement and they are using current and former identity based movements as a template for their own structure and strategy.

"The Internet has given rise to scores of racially conscious websitesmany of them excellent - and it has become easy to find like-minded people...We are still a minority, of course, and it will take a great deal of work to move our ideas fully into the mainstream or to begin to shape policy. We still have nothing like the patriotic political parties that are doing so much good in countries such as Austria, Denmark, and Belgium. And yet, race realism is clearly spreading." (American Renaissance January 1, 2012)

Having recognized the difficulty that lays ahead some contributors to these publications clearly identify what the "movement" needs in order to be successful. They plainly state how the White Nationalist movement can, in their eyes, achieve success by co-opting social movement strategy and rallying behind this idea of Identity politics.

"In this threatening atmosphere of political instability and economic insecurity, old-stock Americans, along with their co-ethnics in England, Canada, and Australasia, will be compelled, sooner or later, to join in the high-stakes game of identity politics." (Occidental Quarterly Summer 2011)

"Race realists are not separatists, believing instead that a vigorous pursuit of identity politics within a multiracial state is enough to safeguard their people's interests" (Occidental Quarterly Fall 2013)

"Only by the majority of the White masses mobilizing under a cooperative and harmonious banner of unity, and determination to fight for the interests, ideals, and objectives of White Power, will we prevail" (NSM newsletter Summer/Fall 2012) 


\section{National Socialist Movement, a $3^{\text {rd }}$ Party Option:}

The analysis of the National Socialist Movement newsletters suggests that they are making a concerted effort to live up to their claim of being "America's Premier White Civil Rights Organization.” The frames of communication in which they engage mirror, in many ways, those used by other civil rights groups across the globe in the last 50 years. They call attention to a system of government that they feel has marginalized their "in-group" and use these examples as a rallying cry for support. The members of the NSM also work to present their message in a way that is engaging and attention grabbing. The use of statistics and data taken out of context, along with co-opting the messages found in right-wing political spheres allows the NSM to cast a wide net in hopes of piquing the interest of the masses so that they might gain the opportunity to slowly indoctrinate a few select individuals to their racially/ethnically extremist ideology.

"Destruction of the White majority is in violation of U.N. Resolution 260A Article 2 provision $C$ in that it: Deliberately inflicts on the group in question conditions of life calculated to bring about its physical destruction in whole or in part." (NSM newsletter Spring/Summer 2013)

"The National Socialist Movement is dedicated to defending the continued promotion of the White Race as the dominant cultural and economic and military power within the borders of these United States" (NSM newsletter Spring/Summer 2013)

The National Socialist Movement is one organization among many whose end game is some varying degree of White racial dominance in the United States. The NSM rallies around the idea that America was founded by White Europeans for White Europeans and their ancestors. They understand the world in which they live and recognize that complete dominance is an impossible goal so they settle for trying to 
achieve economic, political and social superiority and control over other non-White groups in America.

"The National Socialist Movement offers a real alternative to the current situation. We offer real time solutions that benefit all citizens and we pledge to use all legal means necessary to ensure that White America remains firmly in control of this nation. America must remain a White majority to remain America!!!" (NSM newsletter Spring/Summer 2013)

They are not, however, the only organization in America that offers a third party political option built on a foundation of National Socialism. Another nationally present groups with this same political position is called the National Alliance and while they have traded in their Swastika armbands and Adolf Hitler posters, they are still fundamentally the same as the NSM and most any other White Nationalist group in America

\section{The National Alliance, White Pride-World Wide:}

The National Alliance on the other hand seems to be of the opinion that they can be seen as part of a legitimate movement if they seek support through the development of a strong ethnic identity. They rally for the creation of European ethnic festivals and encourage their readers to foster and cultivate an ethnic identity in their families. This tactic allows the National Alliance to more easily employ the use of anti-White and White Nationalist victimization frames when presenting their ideology. The strategy appears to be; encourage an ethnic identity and then highlight both how that identity is under attack and why having that identity is seen as socially or politically incorrect.

"At a recent ethnic festival in Cleveland, an estimated crowd of 70,000 people turned out over a four-day span to celebrate German heritage and culture. This is absolutely amazing and is further proof that the Alliance's new strategy is the correct one." (National Alliance newsletter, June 
"The men in power, of whatever race or creed, are united on the idea that, while it is acceptable for individuals to seek their own destiny as they see fit, the White race has no such right." (National Alliance newsletter March 2011)

Being that both the NSM and National Alliance bill themselves as a "White's only third party" option it makes sense that they would adopt a socially and politically more palatable position on certain issues that they feel affect White Americans. Their use of fear tactics in trying to gain the attention of their "constituency" is not unique to their organization. Strategic parallels between far right-wing extremist groups like the NSM, the National Alliance and right-wing political groups or individuals are undeniable. These parallels will be discussed shortly.

While the National Socialist Movement and the National Alliance center their frames of communication around organized defense of the White racial/ethnic identity and heritage, the Charles Martel Society, with their publication The Occidental Quarterly (TOQ), take a different approach.

\section{The Occidental Quarterly, scholarly racism:}

The Occidental Quarterly is described by its editor, Prof. Kevin MacDonald of Cal State Long Beach, as "a journal devoted to the ethnic, racial, and cultural heritage that forms the foundation of Western Civilization" (www.toqonline.com 2004). Writers for The Occidental Quarterly have been described as "a "Who's Who" of the radical right" by the Southern Poverty Law Center and have what might be called more academic or scholarly frames of communication. The Occidental Quarterly attempt to reach out to White Americans in a way that isn't aggressive. They use a soft-handed approach as a 
means of drawing the attention of their audience and then slowly expose them to more racially and socially divisive ideology.

Many of the articles analyzed contain seemingly non-racist, thought provoking, rhetorical questions or statements such as:

"Young Whites rarely question the fact that Blacks have their own television networks like BET and OWN, while generic, mainstream television has nothing that even hints at the virtues of Western civilization and nothing that singles out White heroes for emulation" (The Occidental Quarterly Fall 2013)

Statements like this are used by The Occidental Quarterly and other "academic racists" in two ways. The first is that for the uninitiated "newbie", that might only be at the beginning of their journey of racial radicalization or even yet to begin it, a statement like this places a wedge in their mind that White Nationalists can then leverage to introduce more racially divisive ideology. It creates questions and potentially doubts in the readers' mind that the writer knows will be there and has answers ready for. Answers that will no doubt be provided within a racialized White Nationalist frame of communication.

The second way statements and the resulting follow-up commentary or discussion are used is in the maintenance of previously establish racialized ideology. These types of statements serve to remind White Nationalists of their beliefs and/or potentially give them one more reason to maintain their belief. It is unlikely that an individual who reads this, or any other statement, in The Occidental Quarterly or a similar publication will take the time to think critically about it or the support provided for it. The writers count on this limited world view and often time's structure the majority of their discussion and topics around it. 
"We also know that we have the ability to communicate with these disaffected Whites, but identifying them and organizing them will not be easy. Esoteric theories and ideologies will not bind them, nor will the fact that we read Nietzsche impress them. We have to present a credible program that will provide the kind of improvement in living standards that has been ongoing for the past 300 years on this continent." (Occidental Quarterly Fall 2013)

The academic or scholarly frames of communication used by The Occidental Quarterly attempt to place it and its publishers in a different White Nationalist group than that of the National Socialists. While the writers and contributors may not be members of any singular or specific White Nationalist group they approach White Nationalism and the need for a White racial/ethnic identity with the same type of social movement mentality. They maintain the idea that White Americans are under attack and only through an organized, concerted effort can they hope to avoid destruction.

"In the absence of a really existing Anglo-Saxon Christian people, the civilizing influence of Anglo-Saxon Christian culture will be extinguished. Anglo-Saxon Christians are already an endangered species" (The Occidental Quarterly Fall 2011)

"It is up to the present generation to fortify its effort to rally the awareness of our global White tribe, to draw a visible line in the sandbox of public opinion, and borrow tactics from our enemies by coming out, acting up, and digging in at every strategic point in the line" (The Occidental Quarterly Fall 2013)

The Charles Martel Society and The Occidental Quarterly are not alone in their scholarly approach to White Nationalism. The benefits of engaging politically and socially conservative populations intellectually, for the purpose of gaining support, is also something that another White Nationalist publication, the American Renaissance, clearly identifies and discusses as a preferred and successful method of engagement. 


\section{American Renaissance, race-realists:}

"However, people do not organize according to theory; they organize according to self- interest, but are also subject to social pressures. People must be approached from within their own experiences. Talking about race and IQ may frighten some people away; talking about heritage, pride, and history is a much easier way to build bridges to White conservatives." (American Renaissance May 2011)

Jared Taylor, editor of American Renaissance, refers to himself as a "race-realist" and as such believes that racial/ethnic difference are real and that racial self-segregation is imperative to the healthy continuation of a racial group. American Renaissance attempts to demonstrate the cultural and intellectual superiority of Whites over all other non-Whites and demonstrate that it is in the best interest of all racial groups to remain separate. American Renaissance presents its supremacist and segregationist ideology using pseudo-scientific reports and also by taking legitimate data or reporting out of context and presenting it as standalone fact.

"If we could separate ourselves just from blacks, who are only about 13 percent of the population, half of all prison inmates, and even more than half of violent criminals would disappear." (American Renaissance September 2011)

"According to Department of Justice statistics blacks are seven to eight times more likely than Whites to be incarcerated." (American Renaissance July 2011)

"Sixty-three percent of British Whites, 43 percent of Asians (which in Britain means Indians and Pakistanis), and 17 percent of blacks agree with the statement that "immigration into Britain has been a bad thing for the country.” (American Renaissance April 2011)

The New Century Foundation doesn't necessarily take a political position in the same way that the National Socialist organizations do. But instead they present their 
argument for racial segregation and White racial superiority as being the obvious choice when presented with their "facts". Their hardline segregationist position is not presented in a purely racist or supremacist way. The case they often try to make as "race realists" is that racial self-segregation is natural and preferred. This, they believe, will allow for the majority of social, economic, and political ills to correct themselves.

"... the only way to forestall this grim future is to resume the racial consciousness and identity that all other groups take for granted, end diversity propaganda, rekindle pride in their accomplishments, and take the only steps that can possibly save them from the void: end immigration and take back the right to free association." (American Renaissance June 2011)

In much the same way that The Occidental Quarterly sets itself up as an intellectual repository for White Nationalists, so does the American Renaissance. The New Century Foundation attempts to "educate" and motivate current and blossoming White Nationalists with its content. The contributors aren't necessarily rallying for a movement led by them but rather calling on all White Americans to educate themselves (with their content of course) and join together as a movement whose goal is a secure, racially homogeneous, White dominated society.

"All the White countries of the world are changing quickly—but in all of them more and more patriots understand that we face a common struggle. American Renaissance will continue to be part of that struggle, but in a different way." (American Renaissance January 1, 2012)

The New Century Foundation and American Renaissance work to publish a newsletter that can be consumed by the politically conservative masses. Both the newsletter and the speaking engagements that occur a few times a year are full of the presentation and discussion of pseudo-scientific data and research statistics that make a 
case for segregation and White racial superiority. One thing that American Renaissance is totally void of appears to be anti-Semitic or conspiratorial content. No instances of either were coded in the newsletters analyzed for this research. According to reports by the Southern Poverty Law Center and the Anti-Defamation League this has brought Mr. Taylor and The New Century Foundation's credibility to question in many White Nationalist circles. His inclusion of Jews in to the "White" category is an unpopular position to say the least. And it has created some friction between him and other organizational leaders and unaffiliated White Nationalists. The absence of anti-Semitic ideology is very rare in White Nationalist discourse, and one publication that makes sure to get its anti-Semitic message out is The American Free Press.

\section{The American Free Press, America's last real newspaper:}

The American Free Press (AFP) has still another way of framing their ideology and presenting it to their audience. Being that AFP is the reincarnation of Willis Carto's The Spotlight, a widely circulated anti-Semitic newspaper that was in print between 1975 and 2001, it is not difficult to understand the frames of communication used by AFP. AFP is similar to other publications in its pronouncements of political failure and antiWhite sentiment being rife within the United States but how they explain it all is slightly different.

"With policies and practices like these, it's not an exaggeration to say that America will become a colony once again with a foreign flag flying over the Capitol.’(AFP January 20, 2014)

"Whites are foolish indeed to willingly head into minority status given the outright hostility shown toward Whites in the mainstream political and media establishment" (AFP December 23, 2013) 
In place of a rally cry for White Civil Rights or the scientific and socio-biological explanations for the problems faced by the White race, AFP falls back on traditional antiSemitism and conspiracy theories.

"Zionist power has been largely built on media influence, which allowed Communism and world Zionism to fundamentally change American culture over the past century." (AFP February 3, 2014)

"This fact, in itself, should straighten out our historical record once and for all but, of course, it will be totally ignored by the television, radio, magazines and newspapers, which are owned and operated by Zionist Jews, to enhance their own agenda of a New World Order." (AFP December 9, 2013)

Willis Carto is not new to the world of virulently anti-Semitic and conspiratorial White Nationalist publishing. He founded the Institute for Historical Review, an organization that promotes Holocaust denial, and also a Populist political advocacy group known as the Liberty Lobby. His position and that of his supporters has always been one of staunch, hardline anti-Semitism. This has always been, and continues to be a theme in his publications. According to Carto, all America's problems are born of Jewish control of the media and government. This is in addition to a Jewish desire for global manipulation and domination.

“... the Trotskyite federal government in D.C. and Zionist international bankers tighten their stranglehold on Americans" (AFP January 6, 2014)

Like other publications, The American Free Press enlists like-minded White Nationalists and members of other organizations to write for the newsletter. Similar themes are present throughout the publication regardless of author and the themes of antiWhite sentiment and a desire to inform White Americans of their plight can be found in nearly every article. As with the following quote taken from an interview with the 
organizer of the White Man March:

"We will make it clear that we will not sit idly by as Whites are discriminated against, mocked, displaced and violently attacked, all of which amount to White genocide, according to the United Nations' own definition of genocide.” (AFP January 27, 2014)

The American Free Press represents the type of publication that is quite honest about its position on the issues of race, politics and White nationalism. It presents itself as an alternative to traditional political discourse and positions in the United States but in a very different way than either of the National Socialist organizations. Much of what is written about and presented in AFP newsletters is best described as social or political commentary with a racist twist. The inclusion of news articles, magazine reports and commentary from political figures like Ron Paul gives AFP the appearance of legitimacy and political credibility. This is also achieved through the self-stated description of both AFP and Willis Carto.

"Willis Carto, arguably the most important radical conservative in postwar America, has shaped the far right's position on such issues as immigration, globalization, multiculturalism, Holocaust denial and the conflict in the Mideast." (AFP January 20, 2014)

The American Free Press knows who its audience is. Little effort is made to adapt its frames of communication for consumption by individuals who don't already, at the very least, reside along the White Nationalist periphery. AFP represents a publication that wants to be sought out by individuals who are traveling the road of racialized radicalization. Its chief purpose appears to be providing "news", commentary and discussion on White Nationalist topics for the purpose of ideological maintenance and support. Willis Carto and his associates aren't holding rallies and leafleting 
neighborhoods. They are observing the world, writing their articles and waiting for people to leave the rallies or read the leaflets and start looking for answers somewhere else. And AFP isn't the only publication that takes this position. Olaf Childress and his First Freedom newsletter have nearly the same approach.

\section{First Freedom, the South will rise again:}

While Olaf Childress and the First Freedom newspaper are best described as NeoConfederate, he certainly doesn't shy away from addressing issues from across the White Nationalist spectrum. Much of content of the First Freedom newsletters analyzed was similar to that of other publications. While it is not uncommon for publications to reprint content from other White Nationalist groups or publications, First Freedom has, very nearly, a majority of unoriginal reprinted content. That being said, both the original, and reprinted content looks very much like that found in the other publications analyzed here. Strong themes of United States political failure being the cause of so much distress felt by White Americans. A near constant discussion about the ills of uncontrolled immigration and the pollution of pure White America. And the requisite conversation about the assault on White Americans and the impending extinction of the White race.

"But, with today's out-of-control federal government, where presidents make war on foreign powers lacking a Congressional declaration, seeking rather U. N. approval; and a Congress whose federal acts directly affect the life, liberty, and happiness of the People" (First Freedom January 2014)

"Our enemies are in the South, flooding beautiful Middle Tennessee with tens of thousands of diseased, Bantu African Muslim savages; our enemies are getting very rich sponsoring the destruction and displacement of our people." (First Freedom October 2013)

"Not only America, but Europe - the homeland of the White race - is 
facing mortal danger. It's life or death for the White race - the race that for all its faults created Western civilization." (First Freedom August 2013)

Since much of the content of First Freedom is reprinted from other sources it made the analysis of the newsletter slightly more taxing but the Neo-Confederate ideology of Mr. Childress can certainly be found in his own writing. In much the same way that Willis Carto and the American Free Press take a position of rallying White Nationalist support around a more specific in-group, so does First Freedom. For Olaf Childress that in-group is traditional Southern Whites. While the White race and White Americans are seen as a threatened group for Mr. Childress, Southern Whites are especially at risk and he devotes much time and attention to informing his readers of the unique threat that the South faces.

"In the rhetoric of radical Left-wing groups such as the Anti-Defamation League and the Southern Poverty Law Center, terms neo-secessionist and neo-Confederate are thrown out haphazardly along with "racist," "terrorist," "neo-Nazi" and "extremist,"” (First Freedom October 2013)

"For twenty years The League of the South [an organization First Freedom is affiliated with] has advocated for the survival, well-being, and independence of the Southern people." (First Freedom September 2013)

Like AFP, First Freedom knows its audience and isn't concerned with offending the moral or social sensibilities of anyone who might disagree with the views expressed in its pages. Though predominately a Neo-Confederate publication the fact that there are reprinted articles from various other White Nationalist sources means that, for the already affiliated or racially radicalized White Nationalist, First Freedom can serve as a collection point for the dissemination of an assortment of White Nationalist beliefs and ideological constructs. With both AFP and First Freedom the frames in thought and the 
frames of communication are much closer together and in many cases the same. That isn't to say there isn't a softening of the message or an adaptation of the frames. Though this most often is present in the inclusion of re-printed content or articles taken from more mainstream media sources.

\section{Right-Wing political overlap:}

Despite organizational, political, and even some ideological differences most all of the content analyzed for this project presented similar themes, messages and beliefs. The idea that White Americans are under attack and the White race faces global extinction at the hands of failing governments, which are secretly controlled by a Jewish cabal, intent on polluting the Aryan bloodline through forced integration policies and unrestricted immigration of Third World minorities is something that was present in all the publications. But this was the idea behind the dialogue. The frames in thought that motivate or drive the frames of communication (Druckman 2001). Another theme found in the newsletters analyzed was the seemingly intentional, targeted co-opting of mainstream political commentary and ideology. Material coded as Right-Wing Political was found in less than half of the articles analyzed (17/44) but its very presence is concerning and needs to be addressed.

It doesn't require much imagination to think that White Nationalists and political conservatives would share some ideologies or beliefs. It also isn't much of a stretch to think that White Nationalists would look to political conservatives as a pool of possible recruits or, at the very least, like minded supporters of their cause. As has been discussed previously, some White Nationalist publications specifically mention ways to address and 
draw in members of the political right-wing. These facts and the presence of so much regurgitated, co-opted, right-wing conservative punditry in the newsletters analyzed gives cause to stop and take a closer examination of not only what White Nationalists are saying but how what they say can and does look very similar to mainstream, socially and politically acceptable speech.

In reporting on a "proposed" mileage tax that would tax American drivers not on the gas the purchase but on the miles they drive, a contributor to the National Socialist Movements' newsletter writes:

"This won't be the last time that Obama and his socialist pals propose an oppressive new tax that no one even imagined before. That's what liberals do: They tax and spend. They won't ever cut their spending enough to balance the budget so that means huge deficits or higher taxes. All the fools who voted for Obama thinking that he was going to lower their taxes should feel free to start kicking themselves about now." (NSM newsletter April 2009)

Reporting on the same story, Fox News contributor Michele Sileo is quoted as saying "Why do you have to know where I'm going now? Sure you're going to say it's because of a tax...The information that this black box (referring to a possible way in which mileage would be tracked) is collecting is just too tempting to not be exploited" (www.foxnews.com October 2013).

In an attempt to highlight the hypocrisy of the United States government an article in First Freedom reports:

"The federal government can require everyone to buy medical insurance, but the State governments are not allowed to compel people to prove they are citizens before they can vote." (First Freedom October 2013)

In a blog about Voter ID laws Right-Wing political pundit Ann Coulter had this to say: "I 
suppose the argument is that by allowing Democrats to steal elections, they can pass all those laws that improve black lives immeasurably, like promoting trial lawyers, gay marriage, abortion and amnesty for illegals" (www.anncoulter.com 2013). It can be reasonably inferred from both reading the rest of the blog and knowing anything about Ann Coulters' opinions of the political Left-Wing that when she refers to "allowing Democrats to steal votes" she is implying that Democrats challenge voter ID laws because those individuals who might not have or are unlikely to have ID would be voting along Democratic party lines.

In one of many discussions surrounding the failed immigration policies of the United States and the burden placed on the average (White) American citizen a National Socialist writer for the National Alliance newsletter highlights the following "facts":

"The economic cost is high, with tax dollars spent on education, medical treatment, and housing costs for illegals." (National Alliance newsletter July/August 2011)

In a report entitled The Fiscal Burden of Illegal Immigration on U.S. Taxpayers (2010), available on its website www.fairus.org, the Federation for American Immigration Reform reports "Illegal immigration costs U.S. taxpayers about $\$ 113$ billion a year at the federal, state and local level. The bulk of the costs — some $\$ 84$ billion are absorbed by state and local governments" and "The annual outlay that illegal aliens cost U.S. taxpayers is an average amount per native-headed household of $\$ 1,117$ ” In an editorial opinion piece for the American Free Press, one individual writes, of President Barack Obama: “It's not 'hope and change,' but 'hope to change.' Hope to change America into a communist country" (AFP February 10, 2014). During an 
appearance at a Tea Party Rally in 2010 former Saturday Night Live comedian and conservative political commentator Victoria Jackson was quoted as saying, "There's a communist living in the White House." (http://videos.nj.com/starledger/2010/04/former_snl_star_victoria_jacks.html). In a 2008 interview on the Fox News program Live Desk, Delaware Republican senate nominee Christine O’Donnell had this to say and Barack Obama when asked who Republicans would prefer to run against in the Presidential election, "He's so Liberal. He's anti-American. He's beating the 'change' drum. But let's look at the change. He did not vote for English as the official language. What does that say?" (www.foxnews.com 2008). 


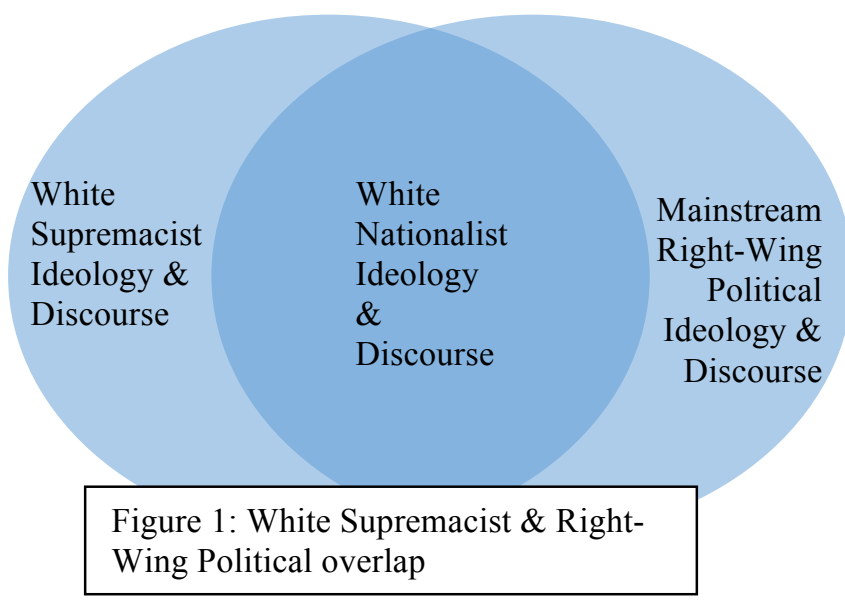

\section{Summary:}

The often times indiscernible differences between comments made by RightWing conservative pundits and those made by Far-Right White Nationalists are of concern. The idea that the frames of communication of these two groups are, often times, so similar as to make telling them apart difficult for someone outside their conservative ideological cohort means that an "in-group" member could very easily get caught in the wide net cast by a White Nationalist group. It is that approach to ideological framing and presentation that was found to be used by all of the organizations and individuals who contribute to the types of White Nationalist publications analyzed. The strategy, of framing and presentation, used by White Nationalists in hopes of rallying people to their cause and convincing people to listen to and consider their racially biased Nationalist message is nearly identical to both the strategy of not only politically conservative social movements but many successful or semi-successful social movements of the last 60 years. It is this identification of strategy and understanding of history that can be used to counteract the effect of White Nationalist frames of communication and also develop 
programs, policies or intervention strategies that may someday see the demise of White Nationalist groups and ideologies.

Having offered a thorough summation of the findings of this research and briefly identifying possible applications of the knowledge gained by it, the following chapter will explore these applications in greater detail. A brief overview of research limitations and steps taken to mitigate their effect on the project will also be provided. Lastly there will a short discussion on research oriented next steps. 


\section{CHAPTER 7 \\ CONCLUSION:}

This final chapter will revisit and summarize the most important points of this research, address some limitations of the study, briefly discuss possible implications of the findings, and offer suggestions for future research.

\section{BOTTOM LINE:}

This project approached the idea of White Nationalist ideological framing and presentation differently than previous content analysis work and as a result identified different emergent themes. A similar foundational theme or strategy could be said to exist in both this work and previous content analysis work; a foundational theme of acceptance and cooptation of mainstream belief with an extremist twist. In their respective work Daniels and Ferber found that White Nationalist held on to extremely traditional gender roles and supported a hyper-traditional patriarchy, two things that at their core can easily be found to have support in mainstream social discourse. Though a different theme the political, social and economic discourse found to be present in the White Nationalist publications I explored held the same trend of acceptance and cooptation.

White Nationalist individuals and organizations are very aware that the world they live in has changed. Social, economic, political and demographic changes have moved them to view the current state of America, and the world, as failing the White race. In many ways their reaction to this perceived threat has been to apply previously successful social movements' strategies to their own struggle. These strategies are applied in slightly different ways depending on the organization or foundational ideology 
of the individuals involved. But at their most basic form they are nearly identical. And as a result of this, it is beneficial to adopt the approach of researchers like Swain and Gardiner and apply social movements' theories to the exploration and analysis of White Nationalist groups.

The framing process used to develop collective action frames of communication by various movement actors are very similar, with slight differences being present that seem to depend on degree of political activism, intended goal of the message and also the targeted population of interest.

\section{Globalized ethnic pride:}

In many respects globalization has made the world smaller. The clothes we wear, the food we eat, the cars we drive and many of the various forms of entertainment we engage in are, at least in part, from somewhere other than the United States. While globalization allows for the United States to import so much in the way of products and goods, it also allows for the export of culture and ideology. This makes the US, as well as much of the western world, a destination for individuals from other countries. But moving to America and becoming “American” doesn't require these new residents and citizens to lose their unique cultural and ethnic identities. This is a point that has not been lost on White Nationalists and in many cases is seen as an example of how the White race and ethnic Europeans are persecuted in the United States.

The rallying cry of "White Pride" has become "European Pride", "Scandinavian Pride", "German Pride” or any variety of other racially White European ethnicity pride. White Nationalists use the idea of globalization both as evidence for claims of White 
"genocide" and as support for developing and maintaining a European ethnic identity. Globalization "threatens" the very existence of the White race by making it easier to engage in cross-racial relationships and supporting non-white ethnic identity while discriminating against White ethnic identity. At the same time globalization has given White Nationalists the tools to build their own ethnic identity and successful examples on which to model their own movement and ideological construction.

\section{A simple strategy:}

An analogy comes to mind when discussing current White Nationalist strategies. It is said that if a live frog is dropped in a pot of hot water it will immediately jump out, recognizing a dramatic change in its environment and correctly perceiving that change as a threat. However, if a frog is placed in a pot of room temperature water and that water is slowly brought to a boil, the frog will not move, will not react and will do nothing to escape its eventual death. White Nationalists are the chef, White Nationalist ideology is the pot of water and White citizens are the frog. Expose people too rapidly to change, they will see it as a threat and react accordingly. But, introduce them to an environment (or idea) similar to their own and slowly change the environment (or idea), they are unlikely to recognize the danger until it is too late.

While attention is still paid to the identification of and hostility toward an "outgroup", from which they are different, much of the current White Nationalist strategy focuses on the "in-group" and the importance of self-preservation. White Nationalists haven't given up on the idea of White racial supremacy but they certainly recognize that, even among political and social conservatives, overt discussions and admissions of White 
racial superiority are likely to turn people off to their message. This is likely to be a motivating factor for the adoption of this relatively new "White Genocide" message and a renewed interest in developing an ethnic identity. They are attempting to brand themselves as pro-White instead of anti-minority in hopes that they will appear less divisive and racially extreme. This, they hope, will allow for an easier approach to and warmer reception by their target demographic. The idea is to get the attention of as many people as possible and slowly expose them to White Nationalist ideology, all the while knowing that the majority of them will not be receptive to the more racially/ethnically biased content. Starting off with "Why isn't there White History Month" is easier to discuss in public than "You know Blacks are genetically inferior and Jews are the spawn of Satan and Eve, right?"

Despite being predominantly critical of both political parties in the United States, White Nationalist are clearly more politically, socially and religiously right-wing. Another critical item uncovered during this research is that the Venn diagram of White supremacist and mainstream right-wing political ideology and discourse is very tightly enclosed.

This is especially concerning when we take in to consideration the rise of "Patriot" groups in the United States, the racialized nature of the "immigration debate", and the amount of covert, thinly veiled racism surrounding discussions of President Barack Obama and his policies. Just as economically disaffected youth can find a home in racist Skinhead groups (Blazak 2001), it stands to reason that politically disaffected Americans can find a home in racially extreme White Nationalist groups when a sense of 
anomie begins to develop and the seek out answers to their questions.

It is this point that is of most use and likely most importance to groups like the SPLC and the ADL. These organizations, and others, work tirelessly to expose White Nationalist organizations and individuals around the world and that work is made more difficult by this overlap of ideology. Armed with the knowledge of new framing processes and frames of communication used by White Nationalist groups, as presented here, anti-hate groups can better develop their own counter-frames. With an understanding that many White Nationalist groups are co-opting a mainstream message and "piggy-backing" on right-wing social and political commentary, these anti-hate groups can refine their processes for identification of these groups as well as the ways the educate the public and help individuals resist White Nationalist recruitment efforts or break free of their indoctrination efforts.

\section{LIMITATIONS:}

While certainly not an exhaustive exploration of White Nationalist discourse this project does add to the existing body of literature on the topic, as well as provide support for the use of New Social Movements theory in the understanding of White Nationalism. As with any research project there are certain limitations that this project operated under. Every effort was made to address them as they were encountered and maintain appropriate and methodologically sound practices in response.

The internet is awash with extremist content of all kinds. Religious, social, political and nationalist content of a radicalized nature can be found to be produced and reproduced on hundreds of thousands of websites. My sample of 44 newsletters 
distributed by six different publishers or publishing organizations is quite literally a drop in the bucket that is White Nationalist content published either digitally or in hard-copy. That being said, I am very confident that my sample and the content within is representative of the great majority of White Nationalist content produced around the globe.

Support for this confidence comes from two sources. The first is that much of the content was suggested and provided by the research team at the Anti-Defamation League, an international anti-hate organization. The ADL was sought out specifically for their expertise in understanding and researching far-right extremist groups. The research team was asked for suggestions of the publications that either had the greatest circulation or had the longest time in print.

The second supporting factor for quasi-representativeness is simply the foundational basis of supremacist or nationalist ideology. All supremacist or nationalist groups share at least one thing in common; they believe they are better, smarter, more deserving, skilled, or advanced than some other group who is not them and those groups should not inter-mingle. Whether it is an unaffiliated, anonymous National Socialist writing a manifesto in a cabin or Jeff Schoep writing from the NSM headquarters in Detroit, Michigan, the ideology, the frames in thought, are similar enough that the analysis of NSM newsletters can be said to be reasonably representative of National Socialism in America. That same logic can be applied to all the content analyzed.

Some academics might raise concerns about using a social movement theoretical lens of analysis and applying the concept of identity politics to White Nationalist groups. 
As mentioned previously, there are questions about whether or not White Nationalist groups meet the criteria for social movements and as such if they can be researched using those theories or concepts most often applied to social movements. My response would be that more often than not a movement isn't recognized as such by the dominant class, group or culture. It matters less that we, the parent culture in America, don't view White Nationalism as a legitimate movement, and more that they do. In fact the not viewing White Nationalism as a social movement does the academic and political community a disservice because it limits the ways in which researchers approach the study and understanding of not only White Nationalism but all forms of ethnic or race based nationalism. It also gives these groups one more point to argue when they are trying to point out the injustice they claim to be fighting against.

\section{IMPLICATIONS \& FUTURE RESEARCH:}

The analysis and findings discussed should be included in development of desistance programs that serve to assist individuals in their exiting White Nationalist groups and counteracting the effect of right-wing racial radicalization. The knowledge and understanding that White Nationalist frames of communication are adapting can also be used in the identification and definition of new far right racial ideology and strategies of radicalization. Hopefully this project and its results are a step toward identification and eventual elimination of racially/ethnically radical frames in thought.

To that end, much more research is needed. Continued and broader analysis of right-wing extremist discourse is necessary in order to keep pace with these radical ideologies and strategies of communication. A deeper understanding of the process of 
racial radicalization would also be immeasurably helpful in that pursuit. While I am not wholly sure what it would look like, I am confident that continued discourse analysis combined with interviews of both producers and consumers of White Nationalist media would serve to expand the understanding of radicalization and ideological framing, presentation and reception. This could be the most beneficial academic approach to the study of White Nationalism.

The work of researchers like Ferber and Daniels examined content that ran up to the mid-90's. The SPLC Hate Watch noted an increase in White Nationalist hate groups starting around the beginning of the $21^{\text {st }}$ century with a significant jump after the election of Barack Obama as President. My research only covers content published between 2009 and 2014 and the themes of nationalism, frustration with American politics and foreign policy are very prevalent. These evidentiary pieces knowledge lead me to believe that something about the early $21^{\text {st }}$ century and the election of Barack Obama facilitated this strategy of mainstream Right-Wing ideological cooptation.

A working hypothesis that could be valuable in its exploration is that the terrorist attacks of September 11, 2001 gave all Americans, and some might say the western world, a common enemy. Muslim extremists became the target of wars. Countries where they resided became the target of global economic sanctions. And unfortunately, individuals who appeared to be Muslim or Middle Eastern became the target of attacks in the United States and elsewhere across the globe. It suddenly became okay for the average citizen to discuss openly their "hatred" of Muslims. Talk of destroying entire countries and groups of people was common place. This may have allowed the White 
Nationalist community the target it needed to serve as a gateway in to the mainstream that would allow for the introduction of individuals to the radicalization "funnel."

Using this same logic and looking at the increase in hate group activity after the 2008 Presidential election, I feel it's worth exploring if and how the identification of Barack Obama, by the far Right, as a potential enemy of America might have created a similar situation to that of $9 / 11$. It brought the issue of race, and especially bi-racial identity to mainstream political discourse in a way that had, as yet, been unseen. While it was beyond the scope of my research question I gained the distinct impression that the identification of a common enemy served as a point of entry in to mainstream discourse for White Nationalists.

Continued use of a social movements approach to the exploration of White Nationalist groups should continue. Modeling studies of racial extremist groups after studies of various social movements will allow for both an academic and civil understanding of how and why White Nationalist groups continue existing. There is also value in reproducing previous studies on White Nationalist groups in order to take stock of the current state of the movement. New explorations in to the motivations of membership, the goals of various groups and the life course of new members would be immensely beneficial. Many studies explored these phenomena in the 80's and 90's but there has been almost no return to these same populations, individuals or methodological approaches since the turn of the $21^{\text {st }}$ century.

It is my hope that this thesis, the theoretical lens of analysis, the methodological approach and the resultant findings/discussion will serve as a piece of a much larger 
puzzle. The academic and social puzzle that is understanding extremist radicalization and ideology in the $21^{\text {st }}$ Century. A puzzle that when (or if) solved will see the end of racial, ethnic, religious, class, gender, political or national bias and extremism. 


\section{REFERENCES:}

Anti-Defamation League (ADL) 2014 http://www.adl.org

Babbie, E. (2013). The basics of social research. Cengage Learning.

Benford, R. D., \& Snow, D. A. (2000). Framing processes and social movements: An overview and assessment. Annual review of sociology, 611-639.

Berbrier, M. (1998). " Half the battle": cultural resonance, framing processes, and ethnic affectations in contemporary white separatist rhetoric. Social problems, 431-450.

------ (2000). The victim ideology of white supremacists and white separatists in the United States. Sociological Focus, 33(2), 175-191.

Berg, B. L., \& Lune, H. (2004). Qualitative research methods for the social sciences (Vol. 5). Boston: Pearson.

Berlet, Chip and Stanislav Vysotsky. 2006. "Overview of U. S. White Supremacist Groups." Journal of Political and Military Sociology, Vol. 34: 11-48.

Bernstein, Mary, (2005) "Identity politics" Annual Review of Sociology, Vol. 31: 47-74

Blazak, R. (1995). The suburbanization of hate: An ethnographic study of the skinhead subculture (Doctoral dissertation, Emory University).

------2001. "White Boys to Terrorist Men: Target Recruitment of Nazi Skinheads."

American

Behavioral Scientist 44(6): pp 982-1000.

-----2004. "'Getting it": The Role of Women in Male Desistance from Hate Groups."

Pp. 161-179 in HOME-GROWN HATE." "Getting it": The Role of Women in

Male Desistance from Hate Groups." United States: Routledge

Blee, Kathleen 1991 Women of the Klan: racism and Gender in the 1920s.

Berkeley, CA University of California Press

------2002. Inside organized racism: women in the hate movement. Berkeley, Regents

------2004. "Women and Organized Racism." Pp. 49-74 in HOME-GROWN HATE.

"Women and Organized Racism." United States: Routledge

------ 2005 'Women and Organized Racial Terrorism in the United States', Studies in Conflict \& Terrorism, vol. 28, pp 421-433

Burris, V., Smith, E., \& Strahm A. (2000). White supremacist networks on the Internet. Sociological Focus, 33 (2) 215-235

Daniels, J. (1997). White lies: Race, class, gender and sexuality in white supremacist 
discourse. Psychology Press.

Essien-Udom, E. U. (1962). Black nationalism: A search for an identity in America (p. 70). Chicago: University of Chicago Press.

Ezekiel, Raphael S. 1995, The Racist Mind: Portraits of American Neo-Nazis and Klansmen, New York: Viking

Ferber, Abby L. 1998a. White Man Falling. Lanham, Rowman \& Littlefield -----1998b. "Constructing whiteness: the intersections of race and gender in US white supremacist discourse", Ethnic and Racial Studies, vol. 21pp 48-63

----- (Ed.). (2004). Home-grown hate: Gender and organized racism. Psychology Press.

Gamson, W. A., Fireman, B., \& Rytina, S. (1982). Encounters with unjust authority (The Dorsey series in sociology)-. Homewood, Ill.: Dorsey Press.

Gardiner, S. L. (2010). White Nationalism Revisited: Demographic Dystopia and White Identity politics. Journal of Hate Studies, 4(1), 59.

Goetz, Stephan J.; Rupasingha, Anil; Loveridge, Scott 2012, "Social Capital, Religion, Wal-Mart, and Hate Groups in America", Social Science Quarterly, vol 93 (2) pp380-393

Hechter, M. (2000). Containing nationalism. Oxford University Press.

Heyes, Cressida, "Identity politics", The Stanford Encyclopedia of Philosophy (Spring 2012 Edition), Edward N. Zalta (ed.), URL = http://plato.stanford.edu/archives/spr2012/entries/identity-politics/

http://www.anncoulter.com/columns/2013-08-14.html

http://www.foxnews.com/politics/2013/10/21/oregon-plan-to-replace-gas-tax-withmilage-tax-raised-concerns-on-privacy-cost/

Kimmel, M., \& Ferber, A. L. (2000). "White Men Are This Nation:” Right Wing Militias and the Restoration of Rural American Masculinity*. Rural Sociology, 65(4), 582-604.

Olzak, S. (2004). Ethnic and nationalist social movements. The Blackwell companion to social movements, 666-693.

Ridgeway, J. (1991). Blood in the face: The Ku Klux Klan, Aryan Nations, Nazi skinheads, and the rise of a new white culture. New York: Thunder's Mouth Press 
Roleff, T. L., Cothran, H., \& Torr, J. D. (2001). Extremist groups: Opposing viewpoints. Greenhaven Press.

Ross, L. (1995). "White Supremacy in the 1990s" in Berlet, C. (Ed.). (1995). Eyes right!: challenging the right wing backlash. Boston: South End Press.

Snow, D. A., \& Benford, R. D. (1988). Ideology, frame resonance, and participant mobilization. International social movement research, 1(1), 197-217.

Snow, D. A., Rochford Jr, E. B., Worden, S. K., \& Benford, R. D. (1986). Frame alignment processes, micromobilization, and movement participation. American sociological review, 464-481.

SPLC (Southern Poverty Law Center). (2013) http://www.splcenter.org/what-we-do/hateand-extremism

Stern, K. S. (1997). A force upon the plain: The American militia movement and the politics of hate. University of Oklahoma Press.

Swain, C. M. (2002). The new white nationalism in America: Its challenge to integration. Cambridge University Press.

Woolf, Linda M.; Hulsizer, Michael R., 2004, "Hate Groups For Dummies: How To Build A Successful Hate Group", Humanity and Society, vol 28 (1) pp40-62 


\section{APPENDIX A: \\ PUBLICATIONS USED IN SAMPLE}

American Free Press-November 25, 2013; December 2, 2013; December 9, 2013;

December 23, 2013; December 30, 2013; January 6, 2014; January 20, 2014; January 27, 2014; February 3, 2014; February 10, 2014

American Renaissance-April 2011-January 2012

The First Freedom-August-October 2013; January 2014

National Alliance Bulletin-August-September 2010; March-October 2011; May-June 2013

Occidental Quarterly_Summer 2011; Fall 2013

National Socialist Movement-April-July 2009; April 2011; Winter/Spring 2012;

Summer/Fall 2012; Spring/Summer 2013 